\title{
Cholinergic Modulation of Stellate Cells in the Mammalian Ventral Cochlear Nucleus
}

\author{
Kiyohiro Fujino and Donata Oertel \\ Department of Physiology, University of Wisconsin, Madison, Wisconsin 53706
}

The main source of excitation to the ventral cochlear nucleus (VCN) is from glutamatergic auditory nerve afferents, but the VCN is also innervated by two groups of cholinergic efferents from the ventral nucleus of the trapezoid body. One arises from collaterals of medial olivocochlear efferents, and the other arises from neurons that project solely to the VCN. This study examines the action of cholinergic inputs on stellate cells in the VCN. T stellate cells, which form one of the ascending auditory pathways to the inferior colliculus, and D stellate cells, which inhibit T stellate cells, are distinguished electrophysiologically. Whole-cell recordings from stellate cells in slices of the VCN of mice demonstrate that most $\mathrm{T}$ stellate cells are excited by cholinergic agonists through three types of receptors, whereas all D stellate cells tested were insensitive to cholinergic agonists. Nicotinic excitation in T stellate cells has two components. The faster component was blocked by $\alpha$-bungarotoxin and methyllycaconitine, suggesting that receptors contained $\alpha 7$ subunits; the slower component was insensitive to both. Muscarinic receptors excite $\mathrm{T}$ stellate cells by blocking a voltage-insensitive, "leak" potassium conductance. Our results suggest that cholinergic efferent innervation enhances excitation by sounds of T stellate cells, opposing the inhibitory action of cholinergic innervation in the cochlea that is conveyed indirectly through the glutamatergic afferents. The inhibitory action of $D$ stellate cells on their targets is probably not affected by cholinergic inputs. Excitation of $\mathrm{T}$ stellate cells by cholinergic efferents would be expected to enhance the encoding of spectral peaks in noise.

Key words: cholinergic efferents; ventral cochlear nucleus; auditory pathways; nicotinic; $\alpha$-bungarotoxin; muscarinic; leak potassium conductance
Neuronal feedback circuits in the afferent pathways of the auditory system are prominent at all levels of the auditory pathway. Cholinergic inputs to the cochlea and to the ventral cochlear nucleus (VCN) arise in the ventral nucleus of the trapezoid body (VNTB) (Sherriff and Henderson, 1994). The medial olivocochlear neurons suppress firing of auditory nerve fibers through the mechanics of the cochlea (Galambos, 1956; Wiederhold and Kiang, 1970; Guinan, 1996). These efferent fibers also innervate the cochlear nuclei directly through collateral branches in most mammalian species (White and Warr, 1983; Brown et al., 1988; Winter et al., 1989). The postsynaptic targets of these neurons are most often the dendrites of stellate cells (Benson and Brown, 1990; Brown and Benson, 1992). A second group of small, cholinergic neurons that lie in the VNTB projects to the magnocellular region of the VCN through the trapezoid body but not to the cochlea (Sherriff and Henderson, 1994). Both muscarinic (Yao and Godfrey, 1995, 1996) and nicotinic (Happe and Morley, 1998; Yao and Godfrey, 1999) acetylcholine receptors have been localized immunohistochemically in the VCN.

The function of cholinergic efferent innervation is only partly understood. The reflex through the olivocochlear efferent neurons

Received May 22, 2001; revised June 19, 2001; accepted July 5, 2001.

This work was supported by National Institutes of Health Grant DC 00176. We are grateful to Inge Siggelkow and Joan Meister for making many liters of solutions and for processing many little tissue slices. We thank Carol Dizack for finishing the anatomical reconstruction figures. We also thank Ramazan Bal and Stephanie Gardner for helping get these experiments started and for valuable suggestions. We also acknowledge Prof. Harunori Ohmori for help with the puff application apparatus.

Correspondence should be addressed to Donata Oertel, Department of Physiology, University of Wisconsin, Medical School, 1300 University Avenue, Madison, WI 53706. E-mail: oertel@physiology.wisc.edu.

Copyright (C) 2001 Society for Neuroscience $\quad 0270-6474 / 01 / 217372-12 \$ 15.00 / 0$ improves the detection of signals in noise in auditory nerve fibers (Winslow and Sachs, 1987; Kawase et al., 1993) and protects the cochlea from noise damage (Rajan, 1988; Reiter and Liberman, 1995). Little is known about the direct action of cholinergic efferents on the cochlear nuclei. Recordings in vivo indicate that cholinergic responses can be either excitatory or inhibitory (Comis and Whitfield, 1968; Starr and Wernick, 1968; Caspary et al., 1983).

In slices it is possible to investigate the action of cholinergic inputs on stellate cells in the VCN in the absence of cochlear effects. Because the VNTB seems to be the only source of cholinergic input to the VCN in rats (Sherriff and Henderson, 1994), it is reasonable to suppose that inputs from the VNTB in mice act on the receptors that are assayed in this study by the application of cholinergic agonists. T stellate cells, named on the basis of their projection through the trapezoid body, form one of the ascending auditory pathways from the $\mathrm{VCN}$ to the inferior colliculus (Oertel et al., 1990). These neurons have relatively high input resistances and thresholds for firing near rest so that even small currents can cause dramatic changes in firing. D Stellate cells are named for the dorsalward projection of their axons (Oertel et al., 1990). They are inhibitory, glycinergic neurons that inhibit the activity of $\mathrm{T}$ stellate cells through local collaterals (Ferragamo et al., 1998) and also inhibit the contralateral cochlear nuclei (Cant and Gaston, 1982; Wenthold, 1987). The present results show that $\mathrm{T}$ stellate cells are excited through both muscarinic and nicotinic receptors. In contrast, D stellate cells are insensitive to cholinergic agonists.

\section{MATERIALS AND METHODS}

All experiments were done in accordance with the protocols and guidelines of the Animal Care and Use Committee at the University of Wisconsin-Madison. 
Slice preparation Coronal brainstem slices containing the VCN were prepared from ICR mice (Harlan Sprague Dawley, Madison, WI) between 18 and 21 postnatal days old. After decapitation, the brain was dissected from the skull in oxygenated normal saline at $31^{\circ} \mathrm{C}$ with minimal stretching of the auditory nerve. The brain was cut coronally at the level of the inferior colliculi. The rostral surface of the specimen was glued onto a Teflon block with a cyanoacrylate glue (Superglue; Loctite Corp., Rocky Hill, CT). Slices of $200 \mu \mathrm{m}$ thickness were cut using an oscillating tissue slicer (Frederick Haer and Co., Brunswick, ME). The slices were allowed to recover at least $1 \mathrm{hr}$ submerged in a holding chamber containing oxygenated normal saline at $33^{\circ} \mathrm{C}$. One slice was then transferred to the recording chamber with a volume of $300 \mu$ l that was superfused continuously at a rate of $\sim 8 \mathrm{ml} / \mathrm{min}$ with oxygenated normal saline maintained at a temperature of $33^{\circ} \mathrm{C}$ by a feedback-controlled heater.

Electrophysiology. Whole-cell patch-clamp recordings in either currentor voltage-clamp mode were made with standard techniques. Patch pipettes were pulled from borosilicate glass capillaries (World Precision Instruments, Sarasota, FL) and were heat-polished before use. The pipette resistance was 5-7 $\mathrm{M} \Omega$ when filled with a K-gluconate-based internal solution. Recordings were made with an Axopatch 200B amplifier and transferred to a computer via a Digidata 1200 interface (Axon Instruments, Foster City, CA). Data were simultaneously recorded with a chart recorder (TA 240; Gould Instrument Systems, Valley View, OH). Stimulus generation, data acquisition, and analyses were performed with pClamp software (version 6; Axon Instruments). Voltages and currents were low pass-filtered at $5 \mathrm{kHz}$ and sampled digitally at $10-25 \mathrm{kHz}$. Series resistance was compensated to $>90 \%$. Voltages were corrected for junction potentials, -5 to $-12 \mathrm{mV}$, depending on the solutions. Numerical data are presented as mean \pm SD with the number of cells tested $(n)$.

Solutions and drugs. The internal pipette solution in most experiments consisted of (in $\mathrm{mm}$ ): $108 \mathrm{~K}$-gluconate, $4.5 \mathrm{MgCl}_{2}, 14$ Tris $_{2}{ }^{-}$ phosphocreatine, $9 \mathrm{HEPES}, 9$ EGTA, $4 \mathrm{Na}_{2}$-ATP, and 0.3 Tris-GTP, pH adjusted to 7.25 with $\mathrm{KOH}$. For studying nicotinic currents in some experiments, K-gluconate was replaced with equimolar concentration of $\mathrm{CsCl}$ to block potassium currents. The normal external saline contained (in $\mathrm{mM}$ ): $130 \mathrm{NaCl}, 3 \mathrm{KCl}, 1.2 \mathrm{KH}_{2} \mathrm{PO}_{4}, 2.4 \mathrm{CaCl}_{2}, 1.3 \mathrm{MgSO}_{4}, 20$ $\mathrm{NaHCO}_{3}, 3 \mathrm{HEPES}$, and 10 glucose, saturated with $95 \% \mathrm{O}_{2}$ and $5 \%$ $\mathrm{CO}_{2}$, pH 7.4 adjusted with $\mathrm{NaOH}$. Experiments that involved extracellular application of $\mathrm{CdCl}_{2}$ and $\mathrm{BaCl}_{2}$ were performed in the following HEPES-buffered solution to prevent precipitation (in $\mathrm{mM}$ ): $138 \mathrm{NaCl}, 4.2$ $\mathrm{KCl}, 2.4 \mathrm{CaCl}_{2}, 1.3 \mathrm{MgCl}_{2}, 10 \mathrm{HEPES}$, and 10 glucose, saturated with $100 \% \mathrm{O}_{2}, \mathrm{pH} 7.4$ adjusted with $\mathrm{NaOH}$. In studies of muscarinic currents, $0.5 \mu \mathrm{M}$ tetrodotoxin (TTX), $40 \mu \mathrm{M}$ 6,7-dinitroquinoxaline-2,3-dione (DNQX), and $1 \mu \mathrm{M}$ strychnine were added to the external solution to block voltage-sensitive sodium currents and glutamatergic and glycinergic synaptic currents. Because strychnine is known to block responses of some nicotinic receptors (Zhang et al., 1996; Cuevas and Berg, 1998; Rothlin et al., 1999), it was avoided in most experiments of the voltageclamp studies of the nicotinic responses.

Agonists and antagonists of muscarinic and nicotinic receptors and of voltage-sensitive ion channels on which they might act were added to the extracellular saline solution in some experiments. Four cholinergic agonists were used: acetylcholine, carbachol (stable analog of acetylcholine that has both muscarinic and nicotinic actions; Taylor, 1993a), muscarine, and nicotine. Atropine sulfate, D-tubocurarine chloride (D-TC), mecamylamine (MEC), $\alpha$-bungarotoxin ( $\alpha$-BTX), and methyllycaconitine (MLA) were used to block cholinergic receptors. 4- $(N$-ethyl- $N$ phenylamino)1,2-dimethyl-6-(methylamino) pyridinium chloride (ZD7288; Tocris, Ballwin, MO) was used to block hyperpolarization-activated cation conductance $\left(I_{\mathrm{h}}\right)$. All drugs were obtained from Sigma (St. Louis, MO) unless otherwise noted. Drugs were applied by bath superfusion unless otherwise noted.

Puff application of drug. In some experiments, acetylcholine or carbachol, dissolved in normal saline, was applied locally by a pressure puff. Application was made by an air pressure pulse $\left(100-200 \mathrm{cmH}_{2} \mathrm{O}\right)$ through a pipette that had a tip diameter of 3-5 $\mu \mathrm{m}$ and was located $\sim 30$ $\mu \mathrm{m}$ from the cell body. The switching of pressure was made by a solenoid valve that was controlled by a stimulator (Master-8, AMPI, Jerusalem, Israel) triggered by the pClamp software.

Visualization of cells. The VCN of live tissue could easily be identified under the Axioskop microscope (Zeiss, Oberkochen, Germany) with a $63 \times$ water immersion lens. It is situated on the edge of the brainstem, ventral to the granule cell lamina and lateral to the restiform body. $\mathrm{T}$ stellate cells were routinely recorded in slices that included tissue that lay just caudal to root of the auditory nerve. In these slices, the octopus cell area that contains uniformly large cells embedded in a dense network of myelinated fibers can be distinguished from the multipolar cell area, which has smaller cells and a rough appearance. The octopus cell area is devoid of stellate cells, whereas in the multipolar cell area, most larger cells are T stellate cells. D stellate cells were found most commonly near the border of the $\mathrm{VCN}$, near the granule cell lamina both anterior and posterior to the root of the auditory nerve.

Histology. In some experiments T and D stellate cells were identified morphologically by the internal dialysis of a pipette solution that included $0.1 \%$ biocytin. Slices were fixed in $4 \%$ paraformaldehyde and stored at $4^{\circ} \mathrm{C}$ for 2-7 d. Biocytin-filled cells were visualized with the avidin-biotinylated horseradish peroxidase complex reaction (Vectastain ABC Elite kit; Vector Laboratories, Burlingame, CA), using nickel- and cobalt-intensified DAB as a chromogen (Zhang and Oertel, 1993). Then slices were resectioned at $60 \mu \mathrm{m}$, mounted on coated slides, and counterstained with cresyl violet to view the labeled cells with respect to the cytoarchitectural boundaries of the cochlear nucleus. To visualize the cells in their entirety, cells were reconstructed with a camera lucida.

\section{RESULTS}

\section{General properties of T and D stellate cells}

Stellate cells were distinguished from other classes of VCN cells, octopus and bushy cells, by the trains of action potentials evoked by depolarizing current pulses (Wu and Oertel, 1984; Oertel et al., 1990; Golding et al., 1995; Ferragamo et al., 1998). Sharpelectrode recordings of anatomically identified cells in parasagittal slices showed that the action potentials of $\mathrm{T}$ stellate cells are followed by brief, stereotyped undershoots, whereas those of D stellate cells have two undershoots comprising consistent, rapid and more variable, slower components (Oertel et al., 1990; Ferragamo et al., 1998). The results presented here are based on patch-clamp recordings from 296 T stellate and $44 \mathrm{D}$ stellate cells in coronal slices that were initially identified on the basis of the shapes of their undershoots. The resting potentials of the two groups of cells were similar; they were $-59.2 \pm 4.4 \mathrm{mV}(n=296)$ for $\mathrm{T}$ stellate cells and $-61.8 \pm 3.0 \mathrm{mV}(n=44)$ for $\mathrm{D}$ stellate cells. Figure 1 shows the responses to depolarizing and hyperpolarizing current pulses in three representative $\mathrm{T}$ stellate (Fig. $1 A-C$ ) and D stellate (Fig. $1 D-F$ ) cells. The expanded traces, shown as insets, illustrate the shapes of undershoots. The undershoots of $\mathrm{T}$ stellate cells rose smoothly and with a monotonically changing rate toward the next action potential, whereas the undershoots of D stellate cells had an inflection in the rise or two distinct hyperpolarizing phases. The present study reveals an additional difference in the inward rectification. The sag toward rest in responses to hyperpolarizing current pulses is more prominent and more rapid in D than in T stellate cells. Even when using a CsCl-based internal solution, current injection performed within $10 \mathrm{sec}$ after achieving a whole-cell recording, before $\mathrm{CsCl}$ diffused far into the cell, allowed the two populations of cells to be distinguished unambiguously on the basis of their electrophysiological properties.

The differences between $\mathrm{T}$ and $\mathrm{D}$ stellate cells are apparent not only in current-clamp but also under voltage-clamp conditions (examples are illustrated in Figs. 6, 8). Hyperpolarizing voltage pulses evoked first a step change in current, the instantaneous current, and then a slowly activating inward current in all stellate cells tested. The instantaneous current reflects the conductance of the cell before the step change in voltage was made. The slowly activating current in $\mathrm{T}$ stellate cells was identified to be a hyperpolarization-activated, mixed cation current $\left(I_{\mathrm{h}}\right)$ by its sensitivity to $50 \mathrm{~nm}$ ZD7288, a specific blocker for $I_{\mathrm{h}}$ (BoSmith et al., 1993; Bal and Oertel, 2000) ( $n=5$, traces not shown). Both the magnitude and rate of rise of the hyperpolarization-activated 
T stellate
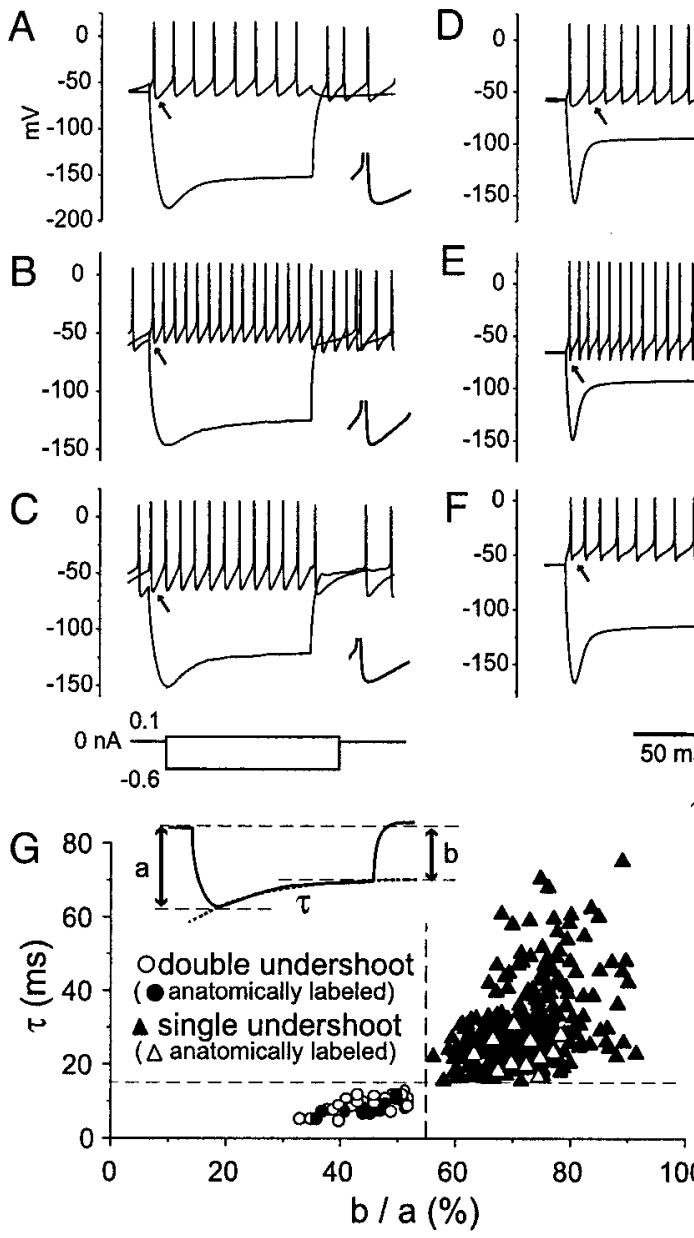

$\tau$ histogram
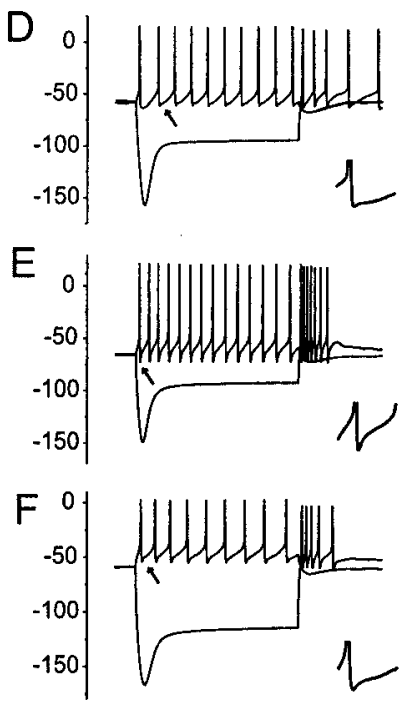

$\overline{50 \mathrm{~ms}}$

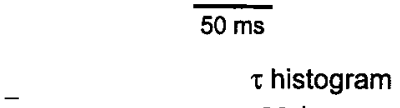

Figure 1. Identification of T and D stellate cells. $A-C$, Voltage responses to depolarizing and hyperpolarizing current pulses in three representative T stellate cells. Action potentials were followed by single undershoots. The response to hyperpolarizing current shows weak inward rectification. $D-F$, Voltage responses to similar current pulses in three representative D stellate cells. In most cells, action potentials were followed by obviously biphasic undershoots. Hyperpolarizing responses show prominent inward rectification. Insets, Expanded traces of the undershoots indicated by arrows (time scale: the full length of the traces corresponds to $8 \mathrm{msec}$ for all insets). Experiments were done using normal external and internal solutions. $G$, Correlation of features shows that T and D stellate cells form distinct populations of neurons. Left inset, Measurements were made of peak hyperpolarization $(a)$ and steady-state hyperpolarization $(b)$, and the sags were fit with a single exponential with time constant $(\tau)$. Open circles, Cells with biphasic undershoots; filled triangles, cells with action potentials whose undershoots are monophasic. The plot shows that cells with rapid sags toward rest (short $\tau$ ) had deeper sags (small $b / a$ ) and had undershoots with two components. The plot is based on responses to 0.6 $\mathrm{nA}$ hyperpolarizing current pulses in 296 cells whose responses fall into the top right cluster and are identified as T stellate cells and 44 whose responses fall into the bottom left cluster and are identified as D stellate cells. Anatomically labeled cells are plotted with filled circles and open triangles, respectively. The dashed lines that separate the two groups lie at $55 \% \mathrm{~b} / \mathrm{a}$ and $15 \mathrm{msec} \tau$. Right, Histogram of distribution of $\tau$ for all cells. The sampling interval was $1 \mathrm{msec}$.

currents differed significantly in the two groups of cells $(p<$ $0.001)$. Hyperpolarization-activated currents were $246 \pm 91 \mathrm{pA}$ in T stellate cells $(n=48)$ and $961 \pm 529 \mathrm{pA}$ in D stellate cells $(n=$ $14)$; the rise of these currents could be fit with single exponentials having time constants of $140 \pm 32 \mathrm{msec}$ in $\mathrm{T}$ stellate cells and

$43 \pm 15 \mathrm{msec}$ in D stellate cells when the voltage was stepped from -60 to $-120 \mathrm{mV}$. The slopes of the current-voltage relationship of instantaneous currents in response to voltage pulses from $-60 \mathrm{mV}$ to between -70 and $-120 \mathrm{mV}$, which reflect the input resistance of cells at rest, were higher in $\mathrm{T}$ stellate cells $(231 \pm 50 \mathrm{M} \Omega ; n=48)$ than in D stellate cells $(148 \pm 68 \mathrm{M} \Omega ; n=$ 14). Probably both differences in recording techniques and a difference in age account for the somewhat higher input resistances than reported previously (Wu and Oertel, 1987; Ferragamo et al., 1998; Golding et al., 1999). As in previous recordings with sharp microelectrodes, many T stellate cells (160 of 296) fired action potentials spontaneously at the resting potential, whereas D stellate cells rarely fired spontaneously (2 of 44).

One test of the reliability of our identification of $\mathrm{T}$ and $\mathrm{D}$ stellate cells was to assess whether the differing characteristics in the populations of T and D stellate cells covaried. An analysis of current-clamp responses of the entire sample of 340 stellate cells shows that stellate cells fall into two groups not only on the basis of the shapes of their undershoots but also on the basis of the rate and amplitude of the inward rectification (Fig. $1 G$ ). Those cells with single undershoots had slow and weak inward rectification, whereas those with double undershoots had rapid and strong inward rectification. Cells that were anatomically confirmed are plotted with contrasting symbols.

An additional test of the reliability of the electrophysiological criteria was to correlate the electrophysiological criteria for identification with anatomically identified, patch-clamped $\mathrm{T}$ and $\mathrm{D}$ stellate cells in the coronal slices used in this study. The camera lucida reconstructions of 2 of the 21 (11 T and $10 \mathrm{D})$ labeled cells are shown in Figure 2. These cells, whose responses to the injection of currents are shown in Figure $1, A$ and $D$, fulfill the criteria that were established to distinguish stellate cells. The T stellate cell has an axon that projects through the trapezoid body; the D stellate cell has an axon that projects dorsalward through the intermediate acoustic stria. D stellate cells, whose distribution can be estimated by immunocytochemical labeling with antibodies to glycine conjugates, are rare in comparison with $\mathrm{T}$ stellate cells in the body of the nucleus (Wickesberg et al., 1994). In the present study, D stellate cells were found most frequently near the border of the anterior part of VCN adjacent to the granule cell lamina.

\section{Cholinergic agonists excite $\mathrm{T}$ but not $\mathrm{D}$ stellate cells}

Cholinergic agonists depolarized $\mathrm{T}$ stellate cells and increased their rate of firing. Figure $3, A-C$, shows an example of the response of a $\mathrm{T}$ stellate cell to the application of cholinergic agonists in the bath. This cell was excited by carbachol, an agonist of both muscarinic and nicotinic receptors (Taylor, 1993a), as well as by muscarine and nicotine. Most of the $\mathrm{T}$ stellate cells tested were excited by $100 \mu \mathrm{M}$ carbachol (15 of 16), indicating that at least $94 \%$ of $\mathrm{T}$ stellate cells have cholinergic receptors. Most T stellate cells were excited by $20 \mu \mathrm{M}$ muscarine (30 of 36) and $2 \mu \mathrm{M}$ nicotine (21 of 25). Most of the cells on which both muscarine and nicotine were tested were excited by both (16 of 21). Excitation was defined in current-clamp experiments as increasing the spontaneous firing rate by $>50 \%$ or depolarizing a cell by $>2 \mathrm{mV}$. The proportion of $\mathrm{T}$ stellate cells excited by cholinergic agonists is likely to be underestimated because of the desensitization of responses.

In contrast, no D stellate cells responded to any of these cholinergic agonists in all 18 cells tested in current-clamp experiments [0 of 3 cells tested with $1 \mathrm{~mm}$ acetylcholine, 0 of 10 cells 


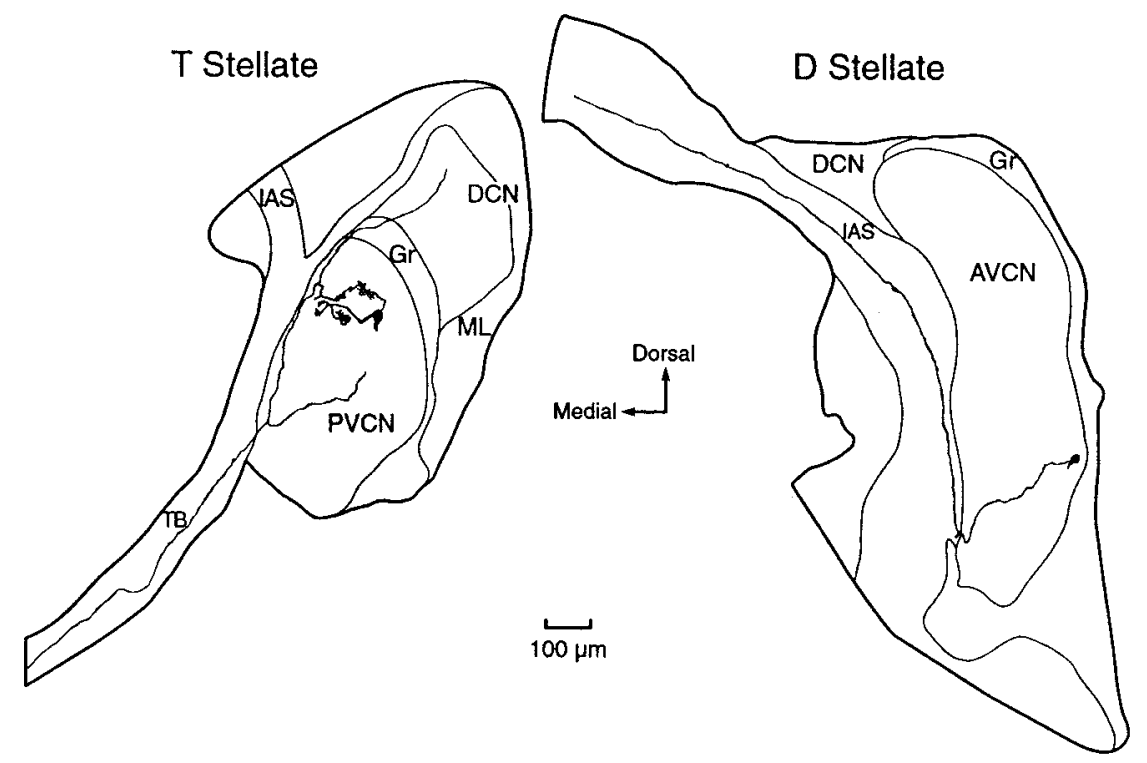

Figure 2. Reconstructions of biocytin-labeled $\mathrm{T}$ and D stellate cells of the VCN. Left, A T stellate cell whose responses to injected current are shown in Figure $1 \mathrm{~A}$ has a branched dendrite with a curly appearance. The axon characteristically projects out of the VCN through the trapezoid body and has collateral branches in the dorsal and ventral cochlear nuclei. Presumably some dendrites had been cut in preparing the slice. Right, D stellate cell whose responses to injected current are shown in Figure $1 D$. The axon characteristically runs dorsally through the intermediate acoustic stria. Presumably the dendrites had been cut in the preparation of the slice. PVCN, Posteroventral cochlear nucleus; $A V C N$, anteroventral cochlear nucleus; $D C N$, dorsal cochlear nucleus; $G r$, granule cell region; $M L$, molecular layer of DCN; $T B$, trapezoid body; $I A S$, intermediate acoustic stria. tested with $100 \mu \mathrm{M}$ carbachol (Fig. 3D), 0 of 7 cells tested with 20 $\mu \mathrm{M}$ muscarine, and 0 of 4 cells tested with $2 \mu \mathrm{M}$ nicotine]. Additional results of tests under voltage-clamp conditions are described below. The $\mathrm{EC}_{50}$ of acetylcholine has been measured for various types of nicotinic receptors. The maximum $\mathrm{EC}_{50}$ for any nicotinic receptor was $350 \mu \mathrm{M}$ (Role, 1992; McGehee and Role, 1995). The maximum $\mathrm{EC}_{50}$ of carbachol for muscarinic receptors is $10 \mu \mathrm{M}$ (Madison et al., 1987; Benson et al., 1988; Bräuner-Osborne and Brann, 1996). The finding that none of the D stellate cells respond to cholinergic agonists even at concentrations that are severalfold higher than the $\mathrm{EC}_{50}$ of the least sensitive receptors makes it likely that D stellate cells are insensitive to acetylcholine.

To understand the mechanisms whereby cholinergic agonists excite T stellate cells, the currents evoked by these agonists were examined under voltage-clamp conditions. Nicotinic currents were evoked by the application of nicotine or by carbachol in the presence of $2 \mu \mathrm{M}$ atropine. The identity of those currents was confirmed by their sensitivity to $50 \mu \mathrm{M}$ D-TC (Taylor, 1993b). Muscarinic currents were evoked by the application of muscarine or by carbachol in the presence of $50 \mu \mathrm{M}$ D-TC. The specificity of the agonist and the identity of those currents were confirmed by their sensitivity to $1 \mu \mathrm{M}$ atropine. Cholinergic agonists were applied in the presence of $40 \mu \mathrm{M}$ DNQX and, in some cases, $1 \mu \mathrm{M}$ strychnine to avoid possible indirect effects of cholinergic agonists on presynaptic terminals (McGehee et al., 1995; Gray et al., 1996). Under control conditions, with and without TTX, frequent miniature EPSCs (mEPSCs) and mIPSCs were observed (Gardner et al., 1999). These mPSCs were all blocked by DNQX and strychnine, suggesting that none was cholinergic. It is not clear whether cholinergic mEPSCs are not present or not detectable.

Clamping the voltage in cells with long dendrites is imperfect, but useful information can still be obtained. The capacitative transient currents were long, sometimes $\sim 10 \mathrm{msec}$, indicating that step changes in voltage were slow in parts of the cell. Curvature in the current-voltage relationship of the instantaneous current in the depolarizing voltage range reflected the activation of a voltage-sensitive potassium conductance whose activation began before the clamp settled. In the voltage range more depolarized than $-40 \mathrm{mV}$, the currents were not always consistent from trial to trial, indicating that the voltage was not reliably clamped. The use of CsCl-based internal solutions or the presence of extracellular $\mathrm{Cs}^{+}$and $\mathrm{Cd}^{2+}$ made the measured currents stable and reproducible even in the depolarized voltage range. The consistent and linear behavior of cholinergic currents in many experiments suggests that at the steady state, the lack of isopotentiality was not usually a major problem.

\section{Cholinergic inputs act on muscarinic as well as fast and slow nicotinic receptors of $T$ stellate cells}

Cholinergic responses of $\mathrm{T}$ stellate cells had three components. The pattern of responses that was recorded most often is illustrated in Figure 4. The cell was held under voltage clamp at -60 $\mathrm{mV}$ while $500 \mu \mathrm{M}$ carbachol was applied with a long $(60-75 \mathrm{sec})$ pressure pulse. In the voltage-clamp condition, inward currents larger than $5 \mathrm{pA}$ at the holding potential of $-60 \mathrm{mV}$ were considered to reflect significant excitation. The onset of the pulse evoked a rapidly activating and rapidly desensitizing component (Fig. $4 A, a$ ). This was followed by a more slowly activating and more slowly desensitizing component (Fig. $4 A, b$ ). A third part of the response showed little desensitization and persisted throughout the pulse (Fig. 4A, $c$ ). These three components were resolved in four of six cells tested. The two faster components were blocked by $50 \mu \mathrm{M} \mathrm{D}$-TC (Fig. 4B), indicating that they were mediated through nicotinic receptors. The slowest component (Fig. $4 B, c^{\prime}$ ) was blocked by $1 \mu \mathrm{M}$ atropine (Fig. $4 C$ ), indicating that it was mediated through muscarinic receptors.

None of the three D stellate cells tested showed responses to puff application of $500 \mu \mathrm{M}$ carbachol $(n=3)$ or $5 \mathrm{~mm}$ acetylcholine $(n=3)($ Fig. $4 D, E)$ or bath application of $1 \mathrm{~mm}$ acetylcholine $(n=3)$ (traces not shown).

\section{Pharmacology of nicotinic receptor-mediated currents in $\mathrm{T}$ stellate cells}

To characterize currents through nicotinic receptors, their sensitivity to antagonists of known specificity was tested. A T stellate cell was held at $-60 \mathrm{mV}$ in an external solution to which $2 \mu \mathrm{M}$ atropine had been added to block muscarinic currents. Nicotinic currents were evoked with the puff application of $500 \mu \mathrm{M}$ carbachol. The interval between pressure pulses was at least 5 min to allow recovery from desensitization. The antagonists were applied in the bath. 


\section{T stellate}
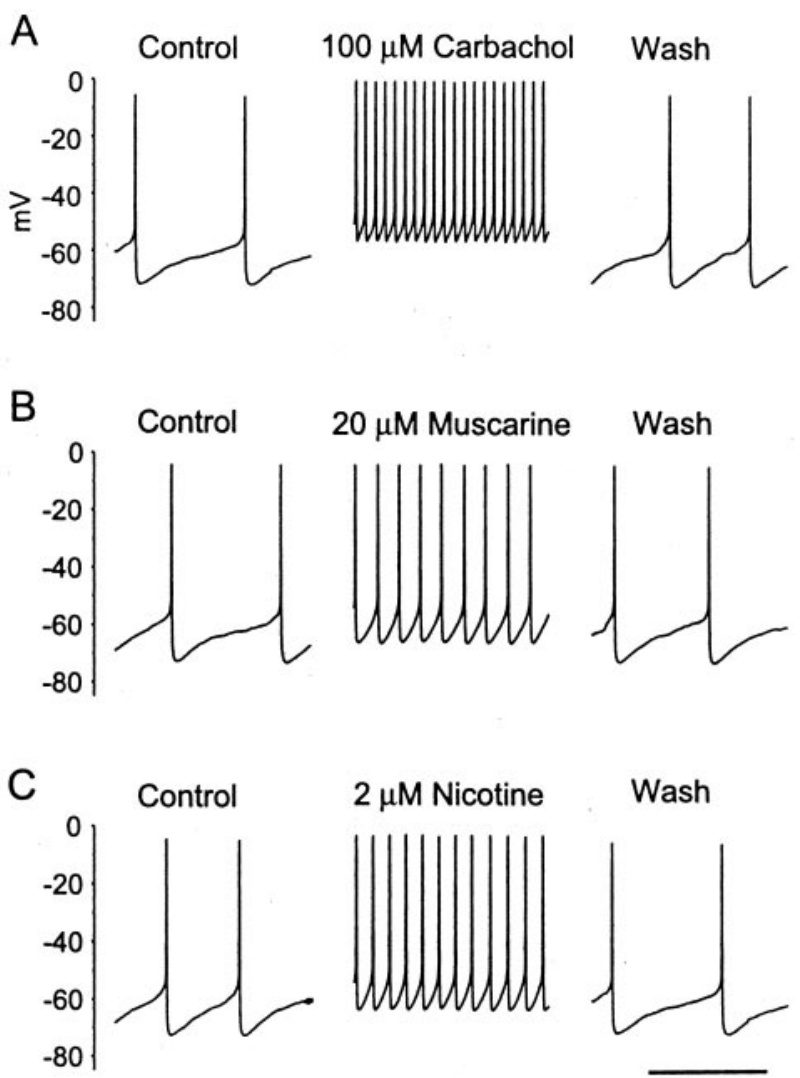

$2 \mu \mathrm{M}$ Nicotine
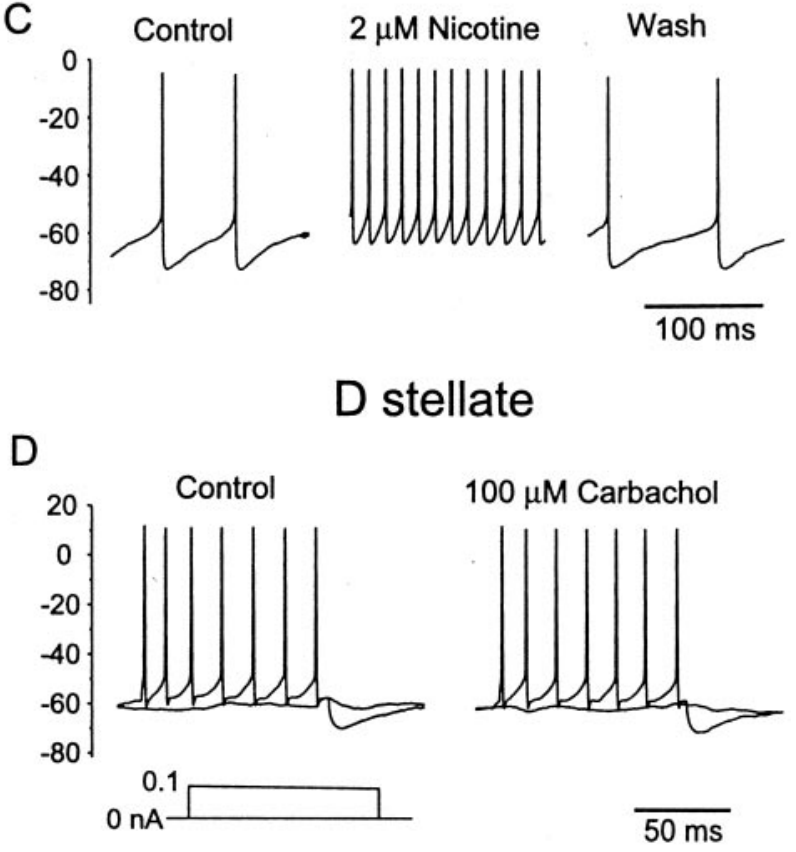

Figure 3. Cholinergic agonists excite a T stellate cell but do not affect a D stellate cell. Bath application of $100 \mu \mathrm{M}$ carbachol $(A), 20 \mu \mathrm{M}$ muscarine $(B)$, and $2 \mu \mathrm{M}$ nicotine $(C)$ increased the spontaneous firing rate of a single T stellate cell reversibly. $D$, The D stellate cell was unaffected by $100 \mu \mathrm{M}$ carbachol. Experiments were done with normal external and internal solutions.

Application of $500 \mu \mathrm{M}$ carbachol with pressure pulses of $1 \mathrm{sec}$ evoked inward currents in $80(83 \%)$ of 96 T stellate cells. Biphasic responses were observed in 57 of $96 \mathrm{~T}$ stellate cells (Fig. 5A-E). Only slowly desensitizing currents were observed in 23 cells, and no response could be resolved in 16 cells. The fast component reached a peak rapidly ( $<50 \mathrm{msec})$, and desensitized within $\sim 300$ msec. The slow component reached a peak more slowly (5-10 sec) and desensitized even more slowly. The mean amplitude of the fast component was $121 \pm 113 \mathrm{pA}(n=57)$, and that of the slow component was $221 \pm 124 \mathrm{pA}(n=57)$.

Pharmacological tests distinguish receptors that contain $\alpha 7$ subunits from those that lack them. Bath application of $50 \mu \mathrm{M}$ D-TC completely and reversibly blocked both the fast and slow components (Fig. $5 A ; n=5$ ). Application of $2 \mu \mathrm{M} \mathrm{MEC} \mathrm{also}$ blocked both components completely and reversibly (Fig. $5 B ; n=$ 4). In contrast, $20 \mathrm{~nm}$ MLA, a specific blocker of receptors that contain $\alpha 7$ subunits (Drasdo et al., 1992; Yu and Role, 1998), blocked the fast component completely and partially reversibly but did not significantly affect the slow component (Fig. 5C; $n=$ 5 ; blocking rate of the slow component was $4.6 \pm 4.0 \%$ ). Another antagonist that is also specific for $\alpha 7$-containing receptors, $100 \mathrm{nM}$ $\alpha$-BTX (Couturier et al., 1990; Bertrand et al., 1992), showed a blocking pattern that was similar to that seen for MLA, but was not reversible (Fig. $5 D ; n=4$; the slow component was reduced by $4.0 \pm 3.0 \%$ ). Strychnine blocks nicotinic receptors with $\alpha 9$ subunits, receptors that have been shown to mediate olivocochlear efferent activity in the cochlea (Elgoyhen et al., 1994; Rothlin et al., 1999; Glowatzki and Fuchs, 2000). It also affects $\alpha 7$-containing nicotinic receptors (Zhang et al., 1996; Cuevas and
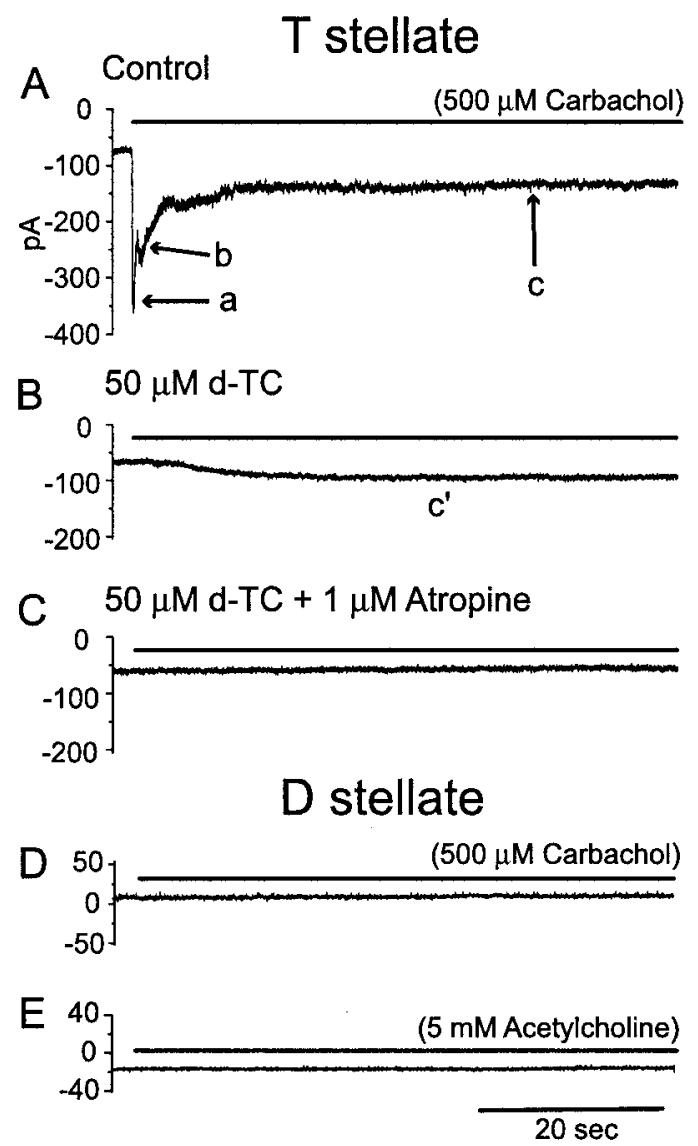

Figure 4. Rapid application of agonist reveals two nicotinic and muscarinic cholinergic currents in $\mathrm{T}$ stellate cells but none in a $\mathrm{D}$ stellate cell. Carbachol $(500 \mu \mathrm{M})$ was applied to a T stellate cell with a pressure pulse (bar). A, Carbachol-evoked inward currents with three components. A rapidly activating and rapidly desensitizing current $(a)$ was followed by a more slowly activating and desensitizing current $(b)$. Some current persisted for the duration of the pulse $(c) . B$, D-TC $(50 \mu \mathrm{M})$ blocked the two faster components, leaving a slow component $\left(c^{\prime}\right)$. The sensitivity of some of the steady-state current to D-TC shows that the nicotinic current desensitized incompletely $(c)$. $C$, The remaining slowest component $\left(c^{\prime}\right)$ was blocked by $1 \mu \mathrm{M}$ atropine. $D$, A D stellate cell was unaffected by the application of $500 \mu \mathrm{M}$ carbachol with a pressure pulse. E, A different D stellate cell was unaffected by puff application $5 \mathrm{~mm}$ acetylcholine. The internal solution was normal; the external solution contained $0.5 \mu \mathrm{M}$ TTX and $40 \mu \mathrm{M}$ DNQX. 


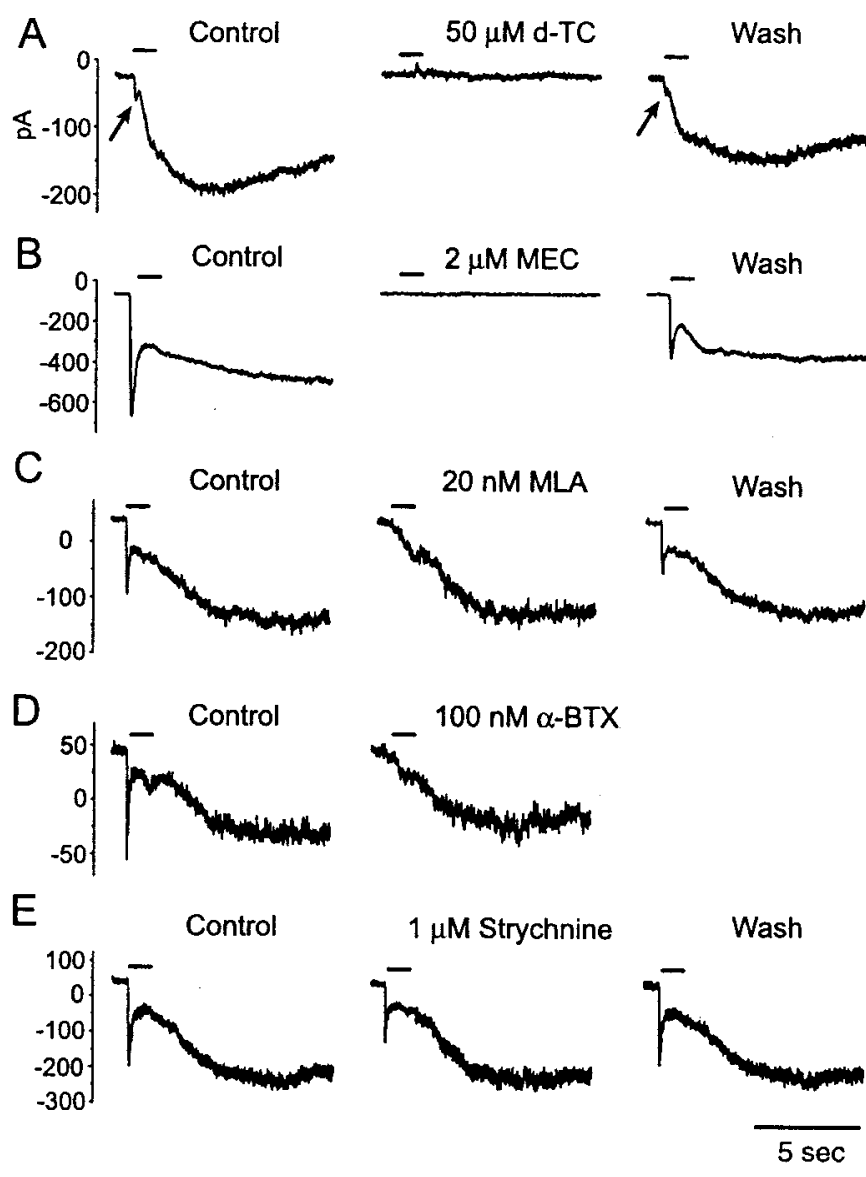

Figure 5. Sensitivity of nicotinic receptor-mediated currents in T stellate cells to cholinergic blockers. Carbachol $(500 \mu \mathrm{M})$ applied with pressure pulses of $1 \mathrm{sec}$ (bar) evoked biphasic inward currents. A, D-TC $(50 \mu \mathrm{M})$ blocked both fast and slow components completely and reversibly. In this cell, the fast component was small (arrow). B, MEC ( $2 \mu \mathrm{M})$ blocked both fast and slow components completely and reversibly. $C$, MLA (20 nM) blocked only the fast component completely and reversibly but did not affect the slow component. $D, \alpha$-BTX $(100 \mu \mathrm{M})$ blocked only the fast component completely and irreversibly but did not affect the slow component. $E$, Strychnine $(1 \mu \mathrm{M})$ reduced the fast component reversibly by $32 \%$. Cells were held at $-60 \mathrm{mV}$. The internal solution was normal; the external solution contained $2 \mu \mathrm{M}$ atropine, $0.5 \mu \mathrm{M}$ TTX, and $40 \mu \mathrm{M}$ DNQX.

Berg, 1998). Application of $1 \mu \mathrm{M}$ strychnine reduced the fast component by $32.8 \pm 6.2 \%(n=4)$ but did not significantly reduce the slow component $(4.0 \pm 2.9 \%)$ (Fig. $5 E$ ). These observations show that most $\mathrm{T}$ stellate cells are excited through two pharmacologically and kinetically distinct groups of nicotinic receptors, only one of which contains $\alpha 7$ subunits.

In 23 cells, only a slow nicotinic current was detected; a rapidly desensitizing component could have been undetected rather than absent. The mean amplitude of these carbachol-induced currents was $214 \pm 179 \mathrm{pA}(n=23)$. They were completely blocked by 50 $\mu \mathrm{M}$ D-TC $(n=3)$ and $2 \mu \mathrm{M}$ MEC $(n=3)$ but almost insensitive to $20 \mathrm{~nm}$ MLA (reduced by $3.5 \pm 2.1 \% ; n=4$ ), $100 \mathrm{~nm} \alpha$-BTX $(2.5 \pm 0.7 \% ; n=2)$, and $1 \mu \mathrm{M}$ strychnine $(3.3 \pm 1.7 \% ; n=3)$.

\section{Biophysical properties of nicotinic receptor-mediated currents}

Nicotine produced a negative shift in the holding current (11 of 14 cells tested) and an increase of the instantaneous current in response to hyperpolarizing voltage pulses (Fig. $6 A$ ). The current reached its peak amplitude $(144 \pm 82 \mathrm{pA} ; n=11)$ within $10-20$ sec. The current evoked by bath-applied nicotine (nicotine minus control) was noisy and, when averaged over the length of the trace, had a linear current-voltage relationship (Fig. 6B,C). The extrapolated reversal potential of this current was $-11.3 \pm 14.7$ $\mathrm{mV}(n=6$; Fig. $6 C)$. The noisiness was not a consequence of a presynaptic effect on glutamatergic or glycinergic inputs, because $40 \mu \mathrm{M}$ DNQX and $1 \mu \mathrm{M}$ strychnine were included in the bath. These observations suggest that this nicotine-evoked inward current is mediated through conventional ligand-gated nicotinic receptors.

Similar tests on two D stellate cells failed to reveal an effect on voltage-dependent or -independent conductances (Fig. 6D).

To improve the quality and voltage range of the voltage clamp, nicotinic currents were measured when $\mathrm{K}^{+}, \mathrm{Ca}^{2+}$, and $I_{\mathrm{h}}$ currents were blocked with a CsCl-based internal solution and by external $200 \mu \mathrm{M} \mathrm{CdCl}_{2}$ and $5 \mathrm{~mm} \mathrm{CsCl}$. Responses to bath application of $100 \mu \mathrm{M}$ carbachol in the presence of $2 \mu \mathrm{M}$ atropine

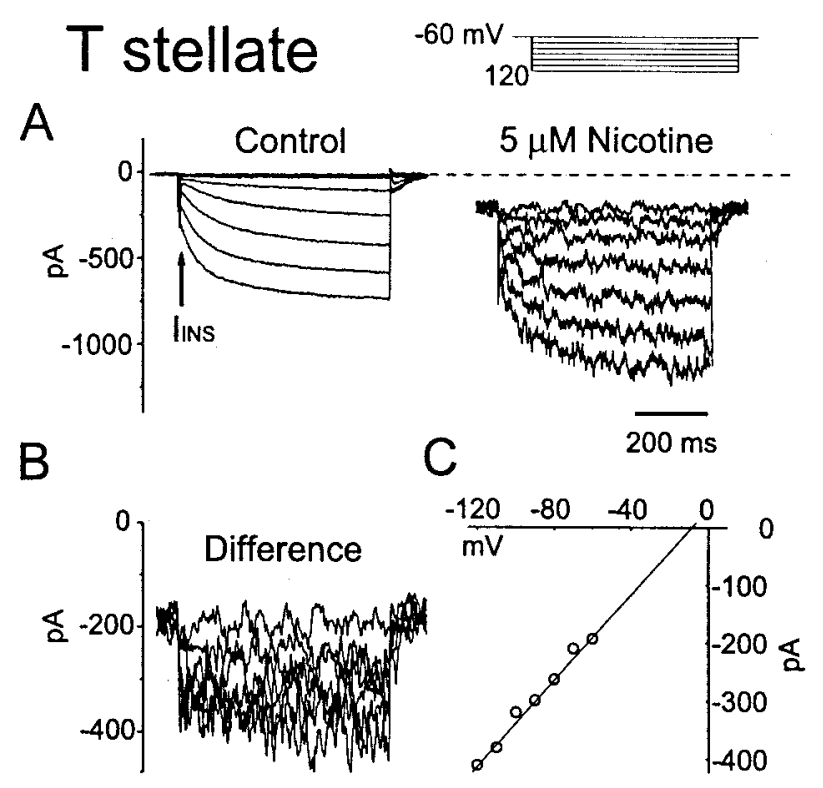

\section{D stellate}

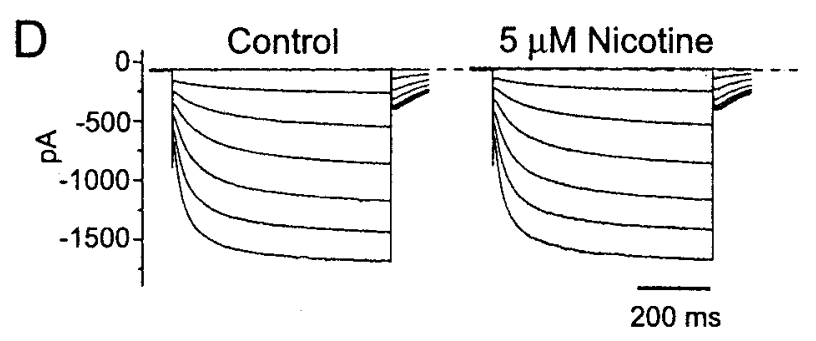

Figure 6. Biophysical properties of currents evoked by bath application of nicotine in a T stellate cell $(A-C)$. $A$, Nicotine $(5 \mu \mathrm{M})$ increased the instantaneous current $\left(I_{I N S}\right)$, elicited a negative shift of the holding current, and increased membrane noise. $B$, The nicotine-evoked difference currents (currents in nicotine minus control currents) obtained from trace-to-trace subtraction. $C, I-V$ relationship of the difference current. The extrapolated reversal potential was $-9.5 \mathrm{mV}$, calculated by the linear fit to the plot. The current amplitudes were averaged through the whole length of each trace. $D$, No response was evoked in a $\mathrm{D}$ stellate cell. The internal solution was normal. The external solution contained $0.5 \mu \mathrm{M}$ TTX, $40 \mu \mathrm{M}$ DNQX, and $1 \mu \mathrm{M}$ strychnine. Note differences in the magnitude and rate of rise of the hyperpolarization-activated currents for the most hyperpolarized pulses $(\tau=98 \mathrm{msec}$ in $A$ and $34 \mathrm{msec}$ in $D)$. 


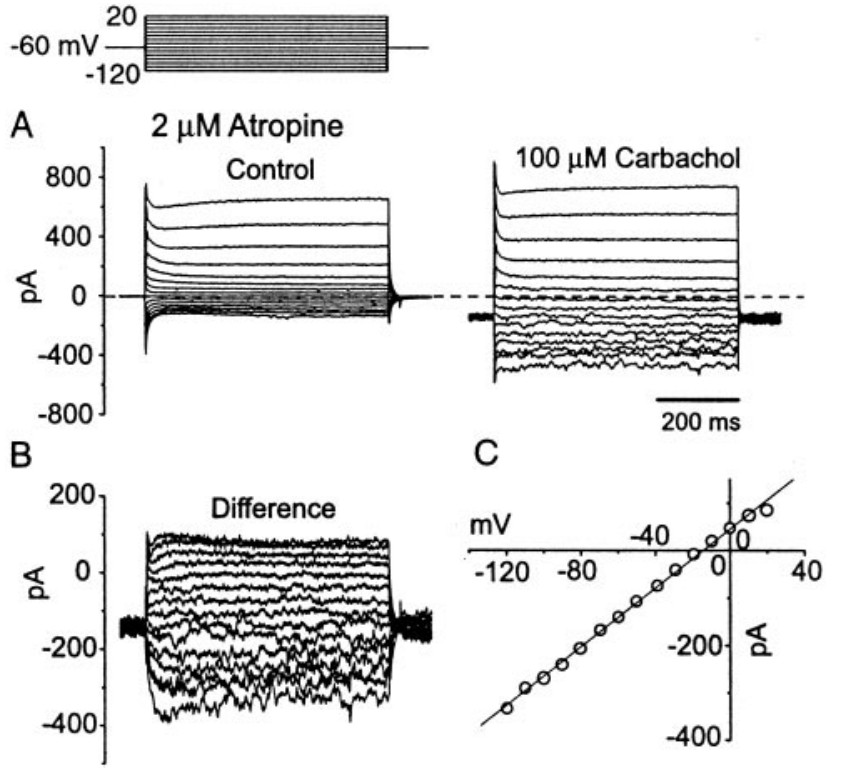

Figure 7. Nicotinic receptor-mediated currents measured with voltage clamp under conditions in which voltage-sensitive conductances were blocked. Pipettes contained a CsCl-based solution; the external solution contained $2 \mu \mathrm{M}$ atropine, $0.5 \mu \mathrm{M}$ TTX, $40 \mu \mathrm{M}$ DNQX, $5 \mathrm{~mm} \mathrm{CsCl}$, and $200 \mu \mathrm{M} \mathrm{CdCl} 2 . A$, Carbachol $(100 \mu \mathrm{M})$ increased the instantaneous current, elicited a negative shift of the holding current, and increased the membrane noise. $B$, The difference currents are primarily voltage- and time-insensitive. $C$, The $I-V$ relationship of the difference current is linear over a wide range of voltage. The current amplitudes were averaged over the whole trace. The reversal potential $(-17.0 \mathrm{mV})$ was calculated by the linear fit to the plot.

resembled those to nicotine when voltage-sensitive currents were not blocked. Carbachol evoked inward currents in 19 of 23 cells tested $(190 \pm 102 \mathrm{pA} ; n=19)$. An increase in noise and an increase in conductance were evident in over the entire voltage range tested between -120 and $+20 \mathrm{mV}$ (Fig. $7 A$ ). The currentvoltage relationship of the current evoked through nicotinic receptors (difference current) was linear and reversed at $-12.9 \pm$ $7.2 \mathrm{mV}$ (Fig. $7 B, C ; n=13$ ). The inward current evoked by carbachol was blocked only slightly by 20 nM MLA $(11.3 \pm 4.0 \%$; $n=3)$ and by $100 \mathrm{nM} \alpha$-BTX $(14.0 \pm 4.3 \% ; n=4)$, indicating that most of it corresponded to the slow nicotinic current; presumably the fast component was largely desensitized.

\section{Biophysical properties of muscarinic receptor-mediated currents}

Muscarinic excitation arises through a decrease in voltageindependent potassium conductance. When $20 \mu \mathrm{M}$ muscarine was applied to the bath while the cell was held at $-60 \mathrm{mV}$, a slow, apparently inward current was observed in 37 of $46 \mathrm{~T}$ stellate cells tested. The inward current reached a peak of $38.7 \pm 22.4 \mathrm{pA}(n=$ 37) within 30-60 sec. To determine the nature of this inward current, hyperpolarizing voltage steps were applied before and during the application of $20 \mu \mathrm{M}$ muscarine. In the presence of muscarine, a negative shift of the holding current was accompanied by a decrease of the instantaneous current and thus by an increase in input resistance (Fig. 8A). This experiment indicates that muscarine acts by decreasing an outward current. The response to muscarine, measured as the difference between the currents evoked in the presence and absence of muscarine, showed little if any voltage sensitivity (Fig. $8 B$ ) and reversed at $-90.6 \pm 5.0 \mathrm{mV}(n=9)$, near the equilibrium potential of potas- sium $\left(E_{\mathrm{K}},-87.2 \mathrm{mV}\right.$; Fig. $\left.8 C\right)$. The slow rise at the onset of the voltage pulse and the small tail currents at the offset of the pulse probably reflected the slow charging and discharging of distant processes in the stellate cell. The increase in input resistance and the reversal near $E_{\mathrm{K}}$ indicates that muscarine excites stellate cells by blocking a voltage-independent $\mathrm{K}^{+}$current. Responses to muscarine were blocked by $1 \mu \mathrm{M}$ atropine $(n=4$; Fig. $8 D)$.

Similar tests on three D stellate cells failed to reveal any effect on conductance change (Fig. $8 E$ ).
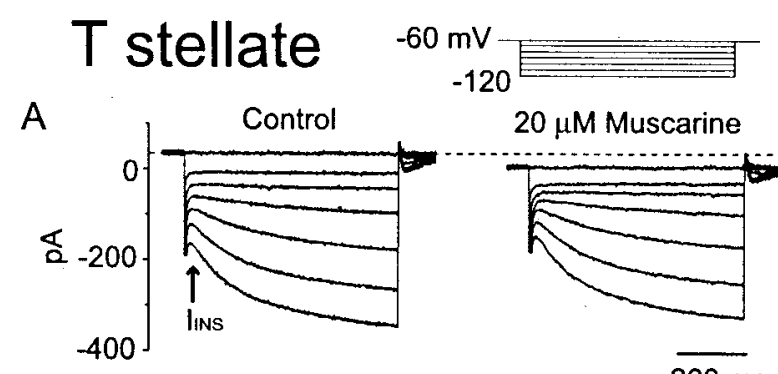

$20 \mu \mathrm{M}$ Muscarine
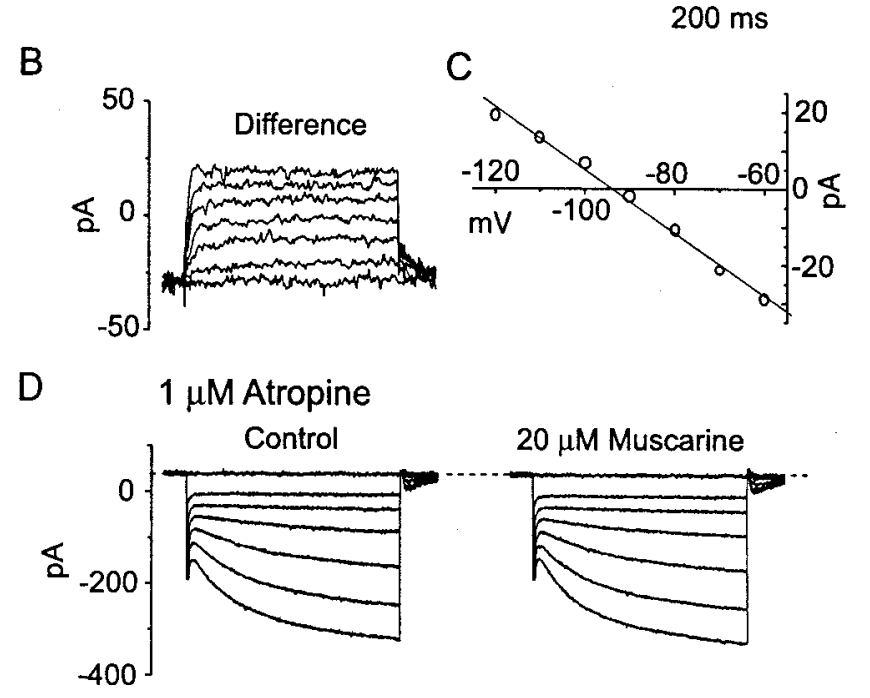

\section{D stellate}

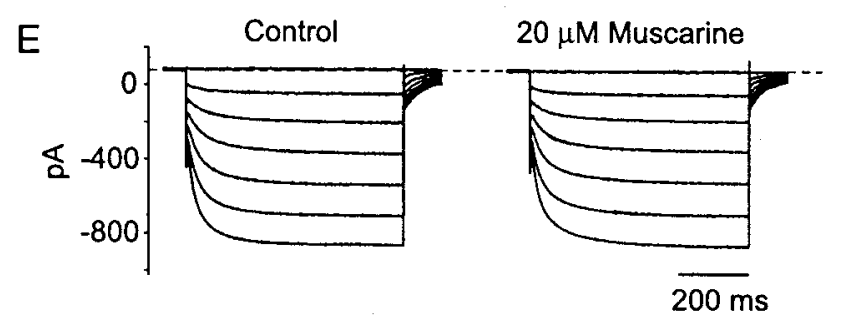

Figure 8. Biophysical properties of currents evoked by bath application of muscarine in a T stellate cell $(A-D)$. $A$, Muscarine $(20 \mu \mathrm{M})$ elicited a decrease of instantaneous current $\left(I_{I N S}\right)$ and a negative shift of the holding current. $B$, The muscarine-evoked difference currents were not obviously time- and voltage-dependent. $C$, The $I-V$ relationship of the difference current was linear. The current amplitudes were averaged through the whole length of each trace. The reversal potential $(-92.8$ $\mathrm{mV}$ ) was calculated from a linear fit of the measurements. $D$, In the presence of $1 \mu \mathrm{M}$ atropine, muscarine did not evoke any response in the same cell whose response is shown in $A$. E, Application of $20 \mu \mathrm{M}$ muscarine to a D stellate cell caused no change. Note that the hyperpolarization-activated current rises more rapidly in the D stellate cell than in the $\mathrm{T}$ stellate cell. The internal solution was normal. The external solution contained $0.5 \mu \mathrm{M}$ TTX, $40 \mu \mathrm{M}$ DNQX, and $1 \mu \mathrm{M}$ strychnine. 


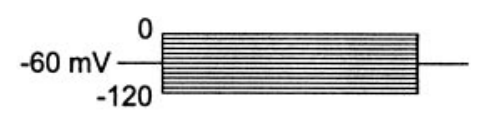

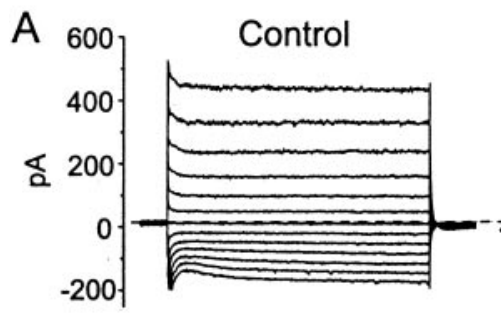

$20 \mu$ M Muscarine

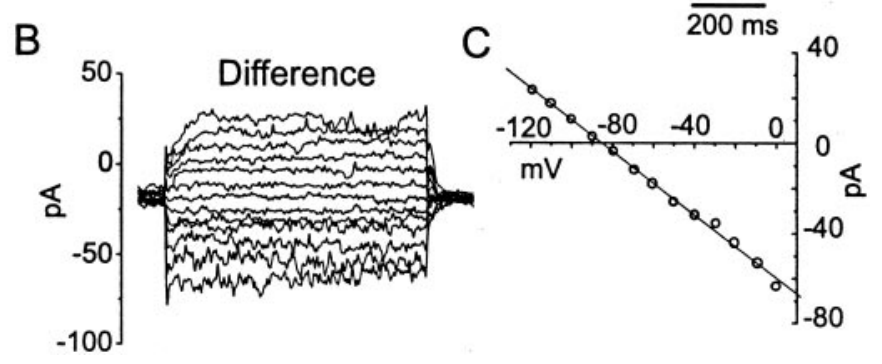

Figure 9. Muscarinic currents measured with voltage clamp under conditions in which voltage-sensitive conductances were blocked. The external solution contained $0.5 \mu \mathrm{M}$ TTX, $40 \mu \mathrm{M}$ DNQX, $1 \mu \mathrm{M}$ strychnine, $5 \mathrm{mM}$ $\mathrm{CsCl}$, and $200 \mu \mathrm{M} \mathrm{CdCl}_{2}$; the internal solution was normal. $A$, Muscarine $(20 \mu \mathrm{M})$ blocked outward and inward currents and elicited a negative shift of the holding current. $B$, The difference current is not obviously time- or voltage-dependent. $C, I-V$ relationship of the difference current. The current amplitudes were averaged through the whole length of each trace. The reversal potential $(-85.4 \mathrm{mV})$ was calculated from a linear fit to the measurements.

To test the voltage sensitivity of the muscarine-induced response with better control over membrane voltage, $I_{\mathrm{h}}$, voltagesensitive $\mathrm{Ca}^{2+}$ currents, and Ca-activated $\mathrm{K}^{+}$currents were blocked by adding $5 \mathrm{mM} \mathrm{CsCl}$ and $200 \mu \mathrm{M} \mathrm{CdCl} l_{2}$ to the external solution. Muscarine reduced both inward and outward currents under these conditions (Fig. 9A). The difference current had a linear current-voltage relationship and reversed at $-87.8 \pm 3.7$ $\mathrm{mV}(n=8)$, near $E_{\mathrm{K}}(-87.2 \mathrm{mV}$; Fig. $9 B, C)$. We conclude that the potassium current blocked by muscarine corresponds to the "leak" potassium current, whose inhibition by muscarine has been reported previously (Madison et al., 1987; Benson et al., 1988; Womble and Moises 1992; Coggan et al., 1994; Guérineau et al., 1994).

$\mathrm{Ba}^{2+}$ has been reported to block the leak $\mathrm{K}^{+}$current (Benson et al., 1988; Coggan et al., 1994). In all three T stellate cells tested, $2 \mathrm{~mm} \mathrm{BaCl}_{2}$ completely blocked the muscarine-evoked responses, indicating that a similar leak $\mathrm{K}^{+}$current mediates muscarinic excitation in T stellate cells (Fig. 10).

Muscarine has been shown to modulate several types of $\mathrm{K}^{+}$ channels. Best known is the $\mathrm{M}$ current $\left(I_{\mathrm{M}}\right.$; Brown and Adams, 1980; Madison et al., 1987; Benson et al., 1988; Womble and Moises, 1992; Coggan et al., 1994). Several experimental observations indicate that the effect of muscarine in T stellate cells is not through such a current. When a T stellate cell was held at -30 $\mathrm{mV}$ and stepped to $-50 \mathrm{mV}$ following the protocol to isolate $I_{\mathrm{M}}$ (Brown and Adams, 1980), neither a slow relaxation current nor a slow tail current was observed ( $n=6$; traces not shown). The muscarine-sensitive current is linear and activated even at -120 $\mathrm{mV}$ (Fig. 8C), at which $I_{\mathrm{M}}$ is not activated (Coggan et al., 1994). In addition, $I_{\mathrm{M}}$ is blocked by $\mathrm{Cs}^{+}$(Coggan et al., 1994), whereas the response to muscarine in $\mathrm{T}$ stellate cells is not different in the presence $(36.7 \pm 17.3 \mathrm{pA} ; n=37)$ and absence $(38.7 \pm 22.4 \mathrm{pA}$; $n=37)$ of $\mathrm{Cs}^{+}$and $\mathrm{Cd}^{2+}$.

Cholinergic synaptic potentials and synaptic currents were not observed. Spontaneous EPSCs recorded at or near the resting potential were blocked by DNQX, indicating that they are mediated by AMPA receptors (Gardner et al., 1999). Neither single shocks $(n=18)$ nor trains of shocks $(n=4)$ through bipolar tungsten electrodes evoked measurable cholinergic EPSPs or EPSCs in any of the cells tested.

\section{DISCUSSION}

T Stellate cells form a major excitatory ascending pathway to the inferior colliculus. They also participate in neuronal circuits that provide feedforward inhibition to the inferior colliculi through the ventral nuclei of the lateral lemniscus (Smith et al., 1993; Schofield and Cant, 1997) and cholinergic feedback inhibition to the cochlea (Smith et al., 1993). The present experiments suggest that the activity in these stellate cells is itself modulated by cholinergic inputs, through a positive feedback loop through the VNTB. Some of this excitation is almost certainly through collateral branches of olivocochlear efferent fibers, which suppress responsiveness to sound in the cochlea. Cholinergic modulation seems not to occur in D stellate cells, glycinergic neurons whose targets include $\mathrm{T}$ stellate cells.

\section{Nicotinic cholinergic responses}

Nicotinic responses are mediated through pentameric, ligandgated receptors. Two forms of the nicotinic acetylcholine receptors predominate in the brain (Role, 1992). One form contains two $\alpha 4$ and three $\beta 2$ subunits and has a high affinity for acetylcholine and a low affinity for $\alpha$-BTX; the second is an $\alpha 7$ homopentamer that has a lower affinity for acetylcholine and a higher affinity for $\alpha$-BTX (Couturier et al., 1990; Bertrand et al., 1992; Yu and Role, 1998). Expression of the $\alpha 7$ subunit is widespread in the brain, including the regions of the VCN in which T stellate cells are most abundant (Séguéla et al., 1993;

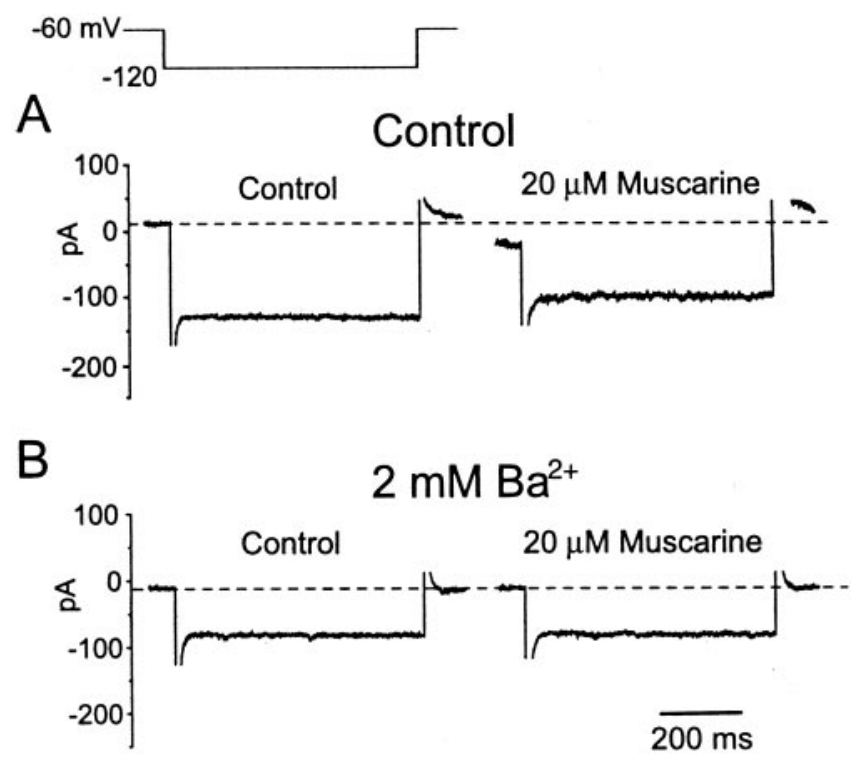

Figure 10. Muscarinic response is sensitive to extracellular $\mathrm{Ba}^{2+}$. The external solution contained $0.5 \mu \mathrm{M}$ TTX, $40 \mu \mathrm{M}$ DNQX, $1 \mu \mathrm{M}$ strychnine, $5 \mathrm{mM} \mathrm{CsCl}$, and $200 \mu \mathrm{M} \mathrm{CdCl}_{2}$; the internal solution was normal. $A$, Muscarine $(20 \mu \mathrm{M})$ decreased the inward current and elicited a negative shift of the holding current. $B$, In the presence of $2 \mathrm{mM} \mathrm{BaCl}_{2}$, muscarine did not evoke any response. 
Happe and Morley, 1998; Yao and Godfrey, 1999). Receptors with $\alpha 9$ subunits mediate cholinergic responses in the cochlea, but expression of $\alpha 9$ subunits in the cochlear nuclei is low (Elgoyhen et al., 1994; Vetter et al., 1999; Glowatzki and Fuchs, 2000). The present experiments show that most $\mathrm{T}$ stellate cells have two types of nicotinic receptors. The rapid desensitization, sensitivity to $\alpha$-BTX and MLA, and slight sensitivity to strychnine suggest that the rapid nicotinic current is mediated through receptors that contain $\alpha 7$ subunits (Zhang et al., 1996; Cuevas and Berg, 1998). The insensitivity to $\alpha$-BTX and MLA indicates that a second group of receptors lacked $\alpha 7$ subunits. Similar biphasic currents and similar sensitivities to $\alpha$-BTX and MLA have been reported in other parts of the brain (Zhang et al., 1994; Pidoplichko et al., 1997; McQuiston and Madison, 1999; Cuevas et al., 2000).

Neither spontaneous nor evoked nicotinic EPSCs could be recorded in $\mathrm{T}$ stellate cells. Many medial olivocochlear fibers terminate in the vicinity of granule cell regions near the branched, distal ends of $\mathrm{T}$ stellate cell dendrites (Benson and Brown, 1990; Brown and Benson, 1992). It is possible that filtering renders mEPSCs difficult to detect at the cell body or that they were so infrequent that they were missed. In other regions of the brain, evoked EPSCs through $\alpha 7$-containing nicotinic receptor had rise times of $<5 \mathrm{msec}$ and decay time constants of 10-30 msec (Frazier et al., 1998; Hefft et al., 1999), whereas the slower EPSCs had rise times of $\sim 10 \mathrm{msec}$ and decay time constants of $>100 \mathrm{msec}$ (Roerig et al., 1997). Cholinergic inputs to T stellate cells are thus probably approximately two orders of magnitude slower than glutamatergic ones, allowing timing information to be encoded in the rapid rise of glutamatergic EPSPs that rides on slower cholinergic depolarizations (Gardner et al., 1999).

\section{Muscarinic cholinergic responses}

Muscarinic cholinergic receptors are G-protein-coupled and have been shown to modulate several $\mathrm{K}^{+}$currents. They suppress the $I_{\mathrm{M}}, \mathrm{Ca}^{2+}$-activated $\mathrm{K}^{+}$current (Brown and Adams, 1980; Madison et al., 1987; Benson et al., 1988; Womble and Moises, 1992; Coggan et al., 1994), inward rectifier $\mathrm{K}^{+}$current (Uchimura and North, 1990; Wang and McKinnon, 1996), and leak $\mathrm{K}^{+}$current (Madison et al., 1987; Benson et al., 1988; Womble and Moises, 1992; Coggan et al., 1994; Guérineau et al., 1994). We show that in $\mathrm{T}$ stellate cells, the activation of muscarinic cholinergic receptors leads to a decrease in a voltage-insensitive leak $\mathrm{K}^{+}$current. Responses through muscarinic receptors rise slowly and last seconds to minutes (Kuba and Koketsu, 1976; Madison et al., 1987; Moises et al., 1995).

\section{Neuronal circuits that involve $T$ and $D$ stellate cells}

The distinction between two types of stellate cells has been confirmed in all species that have been examined. In rodents the two classes of stellate cells have distinct dendritic morphology, projections, and shapes of undershoots (Harrison and Feldman, 1970; Oertel et al., 1990; Doucet and Ryugo, 1997; Ferragamo et al., 1998). The present experiments show that the two types of stellate cells can also be separated on the basis of their inward rectification. In cats, a difference in somatic innervation has been correlated with differences in responses to sound and differences in projection patterns (Cant, 1981; Smith and Rhode, 1989). Corresponding distinctions probably exist also in birds (Harnett and Trussell, 2000; Soares et al., 2000). T stellate cells are excitatory, innervate several brainstem auditory nuclei, including the VNTB, and ultimately project to the contralateral inferior colliculus (Ryugo et al., 1981; Smith et al., 1993). D stellate cells are
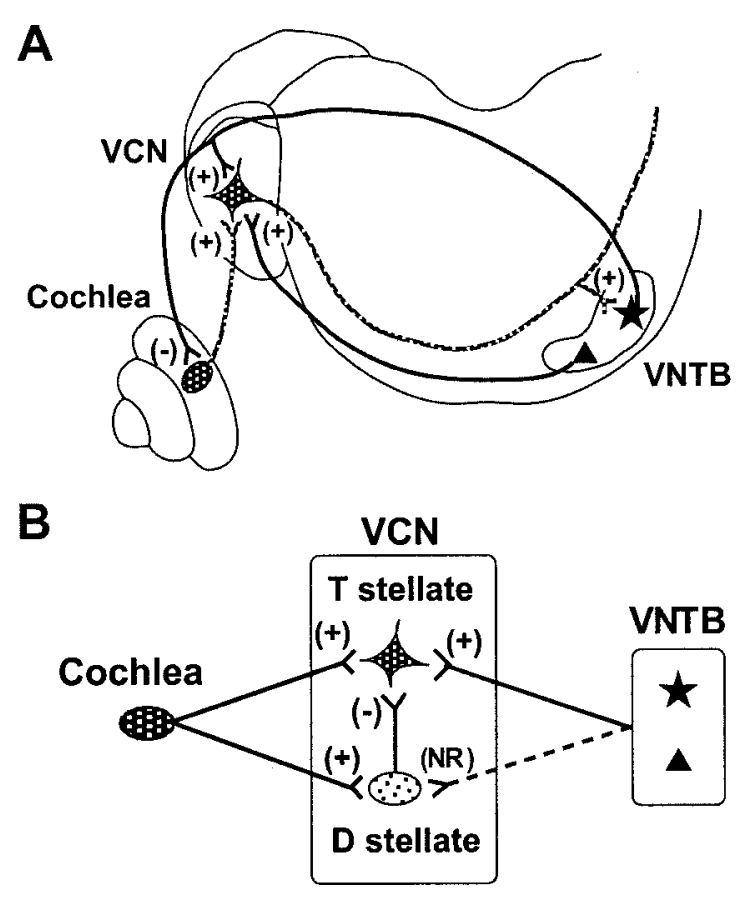

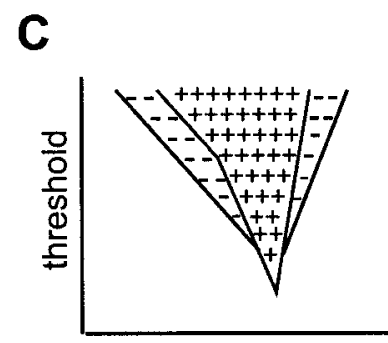

frequency
D

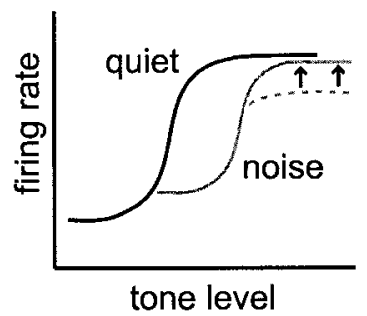

Figure 11. Schematic representations of neuronal circuits that involve cholinergic innervation of the VCN and their implications. $A$, Representation of the feedback loop to the cochlea and to the VCN through two types of cholinergic neurons of the VNTB. The medial olivocochlear efferent neuron ( filled star) innervates both the VCN and the outer hair cells of the cochlea. Acoustic information from inner hair cells is carried to the VCN through spiral ganglion cells (shaded oval) whose axons are the auditory nerve. Smaller cholinergic neurons of the VNTB ( filled triangle) innervate only the VCN. T stellate cells are indicated by the scalloped quadrangle. + , Excitatory connections; - , inhibitory. $B$, VNTB neurons of both types excite T stellate cells but not D stellate cells (large oval). D stellate cells inhibit T stellate cells. Spiral ganglion cells innervate both $\mathrm{T}$ and $\mathrm{D}$ stellate cells. $N R$, No response. $C$, Schematic representation of the responses of $\mathrm{T}$ and $\mathrm{D}$ stellate cells to tones as a function of frequency and intensity. D stellate cells are excited through auditory nerve fibers by tones that fall into a $\mathrm{V}$-shaped range of frequencies and intensities. The frequency at which the threshold is reached at the lowest intensity is the best frequency for the cell. At higher intensities, cells are activated over a broader range of frequencies that is schematically outlined by the line that encloses both + and - symbols. T stellate cells are activated through fewer auditory nerve fibers by tones over a narrower range of frequencies, indicated by the line that encloses the + symbols. The inhibition of $T$ stellate cells by D stellate cells confers inhibitory side bands to the frequency range over which $\mathrm{T}$ stellate cells respond. Except where excitatory responses are near the threshold, excitation of T stellate cells overcomes inhibition (based on Rhode and Greenberg; 1994). D, Proposed mechanism of signal enhancement in noise in $\mathrm{T}$ stellate cells at the best frequency. In noise, cholinergic efferent suppression from the cochlea shifts and compresses the dynamic range of responses of auditory nerve fibers (dashed line). The present results indicate that cholinergic efferents enhance signals in T stellate cells (gray line, arrows), opposing cochlear compression (based on May and Sachs, 1992). 
inhibitory and glycinergic and project to the contralateral cochlear nucleus through the intermediate acoustic stria (Cant and Gaston, 1982; Wenthold, 1987; Wickesberg et al., 1994). The two classes of stellate cells respond differently to sound (Smith and Rhode, 1989). T stellate cells fire tonically (as "choppers") when excitation over a narrow central frequency range balances inhibition from an overlapping, wider frequency range (Shofner and Young, 1985; Rhode and Greenberg, 1994; Palmer et al., 1996) (Fig. 11C). D stellate cells integrate sound energy over a broad range and fire more transiently (as "onset choppers"; Smith and Rhode, 1989; Oertel et al., 1990; Nelken and Young, 1994; Jiang et al., 1996; Palmer et al., 1996).

The broadly tuned D stellate cells are a major source of side band inhibition for the narrowly tuned $\mathrm{T}$ stellate cells. In mice, $\mathrm{T}$ stellate cells receive excitation through approximately five auditory nerve fibers, and they receive inhibition from D stellate cells (Ferragamo et al., 1998). The imposition of broadly tuned inhibition from $\mathrm{D}$ stellate cells on narrowly tuned excitation from auditory nerve fibers accounts for the narrow tuning and inhibitory sidebands of T stellate cells (Fig. 11C) (Shofner and Young, 1985; Rhode and Greenberg, 1994). Whether other sources of inhibition also contribute to inhibitory side bands is not known.

The present results suggest that the VNTB forms an excitatory feedback loop that targets $\mathrm{T}$ but not D stellate cells (Fig. 11 $A, B$ ). All cholinergic inputs to the VCN arise from the VNTB (Sherriff and Henderson, 1994). Responses to sound in the VNTB are driven at least in part through T stellate cell input from the VCN (Thompson and Thompson, 1991; Smith et al., 1993), although the VNTB is known also to receive other inputs (Vetter et al., 1993; Wang and Robertson, 1997a,b; Mulders and Robertson, 2000). Thus the neuronal circuit through the VNTB forms a positive feedback loop whose strength depends on the relative contribution of inputs from $\mathrm{T}$ stellate cells to other inputs. Because there is no evidence of broadband excitation in units with chopper responses, the tuning of medial olivocochlear efferents is likely to be matched to that of their T stellate cell targets. Activity in the medial, cholinergic olivocochlear efferent neurons is driven by tones or noise through either or both ears, has a wide dynamic range, and is delayed by tens of milliseconds with respect to activity in auditory nerve fibers (Robertson and Gummer, 1985; Liberman and Brown, 1986; Liberman, 1988, 1989). Activation of olivocochlear efferents has been shown to improve the representation of signals in noise in auditory nerve fibers (Winslow and Sachs, 1987, 1988; Kawase et al., 1993). Delayed excitation through cholinergic efferents in T stellate cells would be expected to counter adaptation in the firing rate observed in auditory nerve inputs and may account for the larger dynamic range in choppers observed in responses to long rather than short tones (Blackburn and Sachs, 1989).

The positive feedback through the VNTB to T stellate cells would be expected to enhance signaling by $\mathrm{T}$ stellate cells in noisy environments. In enhancing excitation but not inhibition in noise, cholinergic feedback enhances the encoding of spectral peaks over spectral troughs (Fig. 11C). In noise, olivocochlear efferents suppress activity in the cochlea, raising thresholds and shifting and sometimes compressing the dynamic range of auditory nerve fibers inputs to T stellate cells (Guinan, 1996). Cholinergic excitation to $\mathrm{T}$ stellate cells opposes compression, widening the dynamic range and enhancing the encoding of small changes of intensity under noisy conditions (Fig. 11D). The action of cholinergic efferents on $\mathrm{T}$ stellate cells complements their action in auditory nerve fibers, where they also improve the representation of signals in noise (Winslow and Sachs, 1987, 1988; Kawase et al., 1993). An increase in acoustic dynamic range in response to tones long enough to activate the feedback loop and enhancement of spectral peaks in chopper units over other types of units in the ventral cochlear nucleus in the presence of noise have been observed (Blackburn and Sachs, 1989, 1990; May and Sachs, 1992). In behavioral experiments, olivocochlear efferent innervation has been shown to enhance the detection of vowels in noise (Hienz et al., 1998).

\section{REFERENCES}

Bal R, Oertel D (2000) Hyperpolarization-activated, mixed cation current $\left(\mathrm{I}_{h}\right)$ in octopus cell of the mammalian cochlear nucleus. J Neurophysiol 84:806-817.

Benson DM, Blitzer RD, Landau E (1988) An analysis of depolarization produced in guinea-pig hippocampus by the cholinergic receptor stimulation. J Physiol (Lond) 404:479-496.

Benson TE, Brown MC (1990) Synapse formed by olivocochlear axon branches in the mouse cochlear nucleus. J Comp Neurol 295:52-70.

Bertrand D, Bertrand S, Ballivet M (1992) Pharmacological properties of the homomeric $\alpha 7$ receptor. Neurosci Lett 146:87-90.

Blackburn CC, Sachs MB (1989) Classification of unit types in the anteroventral cochlear nucleus: PST histograms and regularity analysis. J Neurophysiol 62:1303-1329.

Blackburn CC, Sachs MB (1990) The representations of the steady-state vowel sound/e/in the discharge patterns of cat anteroventral cochlear nucleus neurons. J Neurophysiol 63:1191-1212.

BoSmith RE, Briggs I, Sturgess NC (1993) Inhibitory actions of ZENECA ZD7288 on whole-cell hyperpolarization activated inward current $\left(\mathrm{I}_{\mathrm{f}}\right)$ in guinea-pig dissociated sinoatrial node cells. Br J Pharmacol 110:343-349.

Bräuner-Osborne H, Brann MR (1996) Pharmacology of muscarinic receptor subtypes (m1-m5): high throughput assays in mammalian cells. Eur J Pharmacol 295:93-102.

Brown DA, Adams PR (1980) Muscarinic suppression of a novel voltage-sensitive $\mathrm{K}^{+}$current in a vertebrate neurone. Nature 283:673-676.

Brown MC, Benson TE (1992) Transneuronal labeling of cochlear nucleus neurons by HRP-labeled auditory nerve fibers and olivocochlear branches in mice. J Comp Neurol 321:645-665.

Brown MC, Liberman MC, Benson TE, Ryugo DK (1988) Brainstem branches from olivocochlear axons in cats and rodents. J Comp Neurol 278:591-603.

Cant NB (1981) The fine structure of two types of stellate cells in the anterior division of the anteroventral cochlear nucleus of the cat. Neuroscience 6:2643-2655.

Cant NB, Gaston KC (1982) Pathways connecting the right and left cochlear nuclei. J Comp Neurol 212:313-326.

Caspary DM, Havey DC, Faingold CL (1983) Effects of acetylcholine on cochlear nucleus neurons. Exp Neurol 82:491-498.

Coggan JS, Purnyn SL, Knoper SR, Kreulen DL (1994) Muscarinic inhibition of two potassium currents in guinea pig prevertebral neurons: differentiation by extracellular cesium. Neuroscience 59:349-361.

Comis SD, Whitfield WE (1968) Influence of centrifugal pathways on unit activity in the cochlear nucleus. J Neurophysiol 31:62-68.

Couturier S, Bertrand D, Matter JM, Hernandez MC, Bertrand S, Miller N, Valera S, Barkas T, Ballivet M (1990) A neuronal nicotinic acetylcholine receptor subunit $(\alpha 7)$ is developmentally regulated and forms a homo-oligometric channel blocked by $\alpha$-BTX. Neuron 5:847-856.

Cuevas J, Berg DK (1998) Mammalian nicotinic receptors with $\alpha 7$ subunits that slowly desensitize and rapidly recover from $\alpha$-bungarotoxin blockade. J Neurosci 18:10335-10344.

Cuevas J, Roth AL, Berg DK (2000) Two distinct classes of functional $\alpha 7$-containing nicotinic receptor on rat superior cervical ganglion neurons. J Physiol (Lond) 525:735-746.

Doucet JR, Ryugo DK (1997) Projections from the ventral cochlear nucleus to the dorsal cochlear nucleus in rats. J Comp Neurol 385:245-264.

Drasdo A, Caulfield M, Bertrand D, Bertrand S, Wonnacott S (1992) Methyllycaconitine: a novel nicotinic antagonist. Mol Cell Neurosci 3:237-243.

Elgoyhen AB, Johnson DS, Boulter J, Vetter DE, Heinemann S (1994) $\alpha 9$ : an acetylcholine receptor with novel pharmacological properties expressed in rat cochlear hair cells. Cell 79:705-715.

Ferragamo MJ, Golding NL, Oertel D (1998) Synaptic inputs to stellate cells in the ventral cochlear nucleus. J Neurophysiol 79:51-63.

Frazier CJ, Buhler AV, Weiner JL, Dunwiddie TV (1998) Synaptic potentials mediated via $\alpha$-bungarotoxin-sensitive nicotinic acetylcholine receptors in rat hippocampal interneurons. J Neurosci 18:8228-8235. 
Galambos R (1956) Suppression of auditory nerve activity by stimulation of efferent fibers to cochlea. J Neurophysiol 19:424-437.

Gardner SM, Trussell LO, Oertel D (1999) Time course and permeation of synaptic AMPA receptors in cochlear nuclear neurons correlate with input. J Neurosci 19:8721-8729.

Glowatzki E, Fuchs PA (2000) Cholinergic synaptic inhibition of inner hair cells in the neonatal mammalian cochlea. Science 288:2366-2368.

Golding NL, Robertson D, Oertel D (1995) Recordings from slices indicate that octopus cells of the cochlear nucleus detect coincident firing of auditory nerve fibers with temporal precision. J Neurosci 15:3138-3153.

Golding NL, Ferragamo MJ, Oertel D (1999) Role of intrinsic conductances underlying responses to transients in octopus cells of the cochlear nucleus. J Neurosci 19:2897-2905.

Gray R, Rajan AS, Radcliffe KA, Yakehiro M, Dani JA (1996) Hippocampal synaptic transmission enhanced by low concentrations of nicotine. Nature 383:713-716.

Guérineau NC, Gähwiler BH, Gerber U (1994) Reduction of resting K ${ }^{+}$ current by metabotropic glutamate and muscarinic receptors in rat $\mathrm{CA} 3$ cells: mediated by G-proteins. J Physiol (Lond) 474:27-33.

Guinan JJ (1996) Physiology of olivocochlear efferents. In: The cochlea (Dallos P, Popper AN, Fay RR, eds), pp 435-502. New York: Springer.

Happe HK, Morley BJ (1998) Nicotinic acetylcholine receptors in rat cochlear nucleus: $\left[{ }^{125} \mathrm{I}\right]$ - $\alpha$-bungarotoxin receptor autoradiography and in situ hybridization of $\alpha 7 \mathrm{nAChR}$ subunit mRNA. J Comp Neurol 397:163-180.

Harnett M, Trussell L (2000) Intrinsic properties of neurons in nucleus angularis. Soc Neurosci Abstr 26:1702.

Harrison JM, Feldman ML (1970) Anatomical aspects of the cochlear nucleus and superior olivary complex. In: Contributions to sensory physiology (Neff WD, ed), pp 95-139. New York: Academic.

Hefft S, Hulo S, Bertrand D, Muller D (1999) Synaptic transmission at nicotinic acetylcholine receptors in rat hippocampal organotypic cultures and slices. J Physiol (Lond) 515:769-776.

Hienz RD, Stiles P, May BJ (1998) Effects of bilateral olivocochlear lesions on vowel formant discrimination in cats. Hear Res 116:10-20.

Jiang D, Palmer AR, Winter IM (1996) Frequency extent of two-tone facilitation in onset units in the ventral cochlear nucleus. J Neurophysiol 75:380-395.

Kawase T, Delgutte B, Liberman MC (1993) Antimasking effects of the olivocochlear reflex. II. Enhancement of auditory-nerve response to masked tones. J Neurophysiol 70:2533-2549.

Kuba K, Koketsu K (1976) Analysis of the slow excitatory postsynaptic potential in bullfrog sympathetic ganglion cells. Jpn J Physiol 26:651-669.

Liberman MC (1988) Response properties of cochlear efferent neurons: monaural vs. binaural stimulation and the effects of noise. J Neurophysiol 60:1779-1798.

Liberman MC (1989) Rapid assessment of sound-evoked olivocochlear feedback: suppression of compound action potentials by contralateral sound. Hear Res 38:47-56.

Liberman MC, Brown MC (1986) Physiology and anatomy of single olivocochlear neurons in the cat. Hear Res 24:17-36.

Madison DV, Lancaster B, Nicoll RA (1987) Voltage clamp analysis of cholinergic action in the hippocampus. J Neurosci 7:733-741.

May BJ, Sachs MB (1992) Dynamic range of neural rate responses in the ventral cochlear nucleus of awake cats. J Neurophysiol 68:1589-1602.

McGehee DS, Role LW (1995) Physiological diversity of nicotinic acetylcholine receptors expressed by vertebrate neurons. Annu Rev Physiol 57:521-546.

McGehee DS, Heath MJ, Gelber S, Devay P, Role LW (1995) Nicotine enhancement of fast excitatory synaptic transmission in CNS by presynaptic receptors. Science 269:1692-1696.

McQuiston AR, Madison DV (1999) Nicotinic receptor activation excites distinct subtypes of interneurons in the rat hippocampus. J Neurosci 19:2887-2896.

Moises HC, Womble MD, Washburn MS, Williams LR (1995) Nerve growth factor facilitates cholinergic neurotransmission between nucleus basalis and the amygdala in rat: an electrophysiological analysis. J Neurosci 15:8131-8142.

Mulders WH, Robertson D (2000) Evidence for direct cortical innervation of medial olivocochlear neurones in rats. Hear Res 144:65-72.

Nelken I, Young ED (1994) Two separate inhibitory mechanisms shape the responses of dorsal cochlear nucleus type IV units to narrowband and wideband stimuli. J Neurophysiol 71:2446-2462.

Oertel D, Wu SH, Garb MW, Dizack C (1990) Morphology and physiology of cells in slice preparations of the posteroventral cochlear nucleus of mice. J Comp Neurol 295:136-154.

Palmer AR, Jiang D, Marshall DH (1996) Responses of ventral cochlear nucleus onset and chopper units as a function of signal bandwidth. J Neurophysiol 75:780-794.

Pidoplichko VI, DeBiasi M, Williams JT, Dani JA (1997) Nicotine activates and desensitizes midbrain dopamine neurons. Nature 390:401-404.

Rajan R (1988) Effect of electrical stimulation of the crossed olivoco- chlear bundle on temporary threshold shifts in auditory sensitivity. I. Dependence on electrical stimulation parameters. J Neurophysio 60:549-568.

Reiter ER, Liberman MC (1995) Efferent-mediated protection from acoustic overexposure: relation to slow effects of olivocochlear stimulation. J Neurophysiol 73:506-514.

Rhode WS, Greenberg S (1994) Lateral suppression and inhibition in the cochlear nucleus of the cat. J Neurophysiol 71:493-514.

Robertson D, Gummer M (1985) Physiological and morphological characterization of efferent neurones in the guinea pig cochlea. Hear Res 20:63-77.

Roerig B, Nelson DA, Katz LC (1997) Fast synaptic signaling by nicotinic acetylcholine and serotonin $5-\mathrm{HT}_{3}$ receptors in developing visual cortex. J Neurosci 17:8353-8362.

Role LW (1992) Diversity in primary structure and function of neuronal nicotinic acetylcholine receptor channels. Curr Opin Neurobiol 2:254-262.

Rothlin CV, Katz E, Verbitsky M, Elgoyhen AB (1999) The $\alpha 9$ nicotinic acetylcholine receptor shares pharmacological properties with type A gamma-aminobutyric acid, glycine, and type 3 serotonin receptors. Mol Pharmacol 55:248-254.

Ryugo DK, Willard FH, Fekete DM (1981) Differential afferent projections to the inferior colliculus from the cochlear nucleus in the albino mouse. Brain Res 210:342-349.

Schofield BR, Cant NB (1997) Ventral nucleus of the lateral lemniscus in guinea pigs: cytoarchitecture and inputs from the cochlear nucleus. J Comp Neurol 379:363-385.

Séguéla P, Wadiche J, Dineley-Miller K, Dani JA, Patrick JW (1993) Molecular cloning, functional properties, and distribution of rat brain $\alpha 7$ : a nicotinic cation channel highly permeable to calcium. J Neurosci 13:596-604.

Sherriff FE, Henderson Z (1994) Cholinergic neurons in the ventral trapezoid nucleus project to the cochlear nuclei in the rat. Neuroscience 58:627-633

Shofner WP, Young ED (1985) Excitatory/inhibitory response types in the cochlear nucleus: relationships to discharge patterns and responses to electrical stimulation of the auditory nerve. J Neurophysio 54:917-939.

Smith PH, Rhode WS (1989) Structural and functional properties distinguish two types of multipolar cells in the ventral cochlear nucleus. J Comp Neurol 282:595-616.

Smith PH, Joris PX, Banks MI, Yin TCT (1993) Responses of cochlear nucleus cells and projections of their axons. In: The mammalian cochlear nuclei: organization and function (Merchan MA, Juiz JM Godfrey DA, Mugnaini E, eds), pp 349-360. New York: Plenum.

Soares D, Hyson RL, Code RA, Carr CE (2000) The intrinsic physiological and morphological characteristics of the chicken nucleus angularis. Soc Neurosci Abstr 26:1702.

Starr A, Wernick JS (1968) Olivocochlear bundle stimulation: effects on spontaneous and tone-evoked activities of single units in cat cochlear nucleus. J Neurophysiol 31:549-564.

Taylor P (1993a) Cholinergic agonists. In: The pharmacological basis of therapeutics, Ed 8 (Goodman LS, Gilman A, Rall TW, Nies AS, Taylor P, eds), pp 122-130. New York: McGraw-Hill.

Taylor P (1993b) Agents acting at neuromuscular junction and autonomic ganglia. In: The pharmacological basis of therapeutics, Ed 8 (Goodman LS, Gilman A, Rall TW, Nies AS, Taylor P, eds), pp 166-186. New York: McGraw-Hill.

Thompson AM, Thompson GC (1991) Posteroventral cochlear nucleus projections to olivocochlear neurons. J Comp Neurol 303:267-285.

Uchimura N, North RA (1990) Muscarine reduces inwardly rectifying potassium conductance in rat nucleus accumbens neurons. J Physiol (Lond) 422:369-380.

Vetter DE, Saldana E, Mugnaini E (1993) Inputs from the inferior colliculus to medial olivocochlear neurons in the rat: a double label study with PHA-L and cholera toxin. Hear Res 70:173-186.

Vetter DE, Liberman MC, Mann J, Barhanin J, Boulter J, Brown MC, Saffiote-Kolman J, Heinemann SF, Elgoyhen AB (1999) Role of $\alpha 9$ nicotinic $\mathrm{ACh}$ receptor subunits in the development and function of cochlear efferent innervation. Neuron 23:93-103.

Wang H-S, McKinnon D (1996) Modulation of inwardly rectifying currents in rat sympathetic neurones by muscarinic receptors. J Physiol (Lond) 492:467-478.

Wang X, Robertson D (1997a) Effects of bioamines and peptides on neurones in the ventral nucleus of the trapezoid body and rostral periolivary regions of the rat superior olivary complex: an in vitro investigation. Hear Res 106:20-28.

Wang X, Robertson D (1997b) Two types of actions of norepinephrine on identified auditory efferent neurons in rat brain stem slices. J Neurophysiol 78:1800-1810.

Wenthold RJ (1987) Evidence for a glycinergic pathway connecting the two cochlear nuclei: an immunocytochemical and retrograde transport study. Brain Res 415:183-187.

White JS, Warr WB (1983) The dual origins of the olivocochlear bundle in the albino rat. J Comp Neurol 219:203-214. 
Wickesberg RE, Whitlon D, Oertel D (1994) In vitro modulation of somatic glycine-like immunoreactivity in presumed glycinergic neurons. J Comp Neurol 339:311-327.

Wiederhold ML, Kiang NYS (1970) Effects of electric stimulation of the crossed olivocochlear bundle on single auditory-nerve fibers in the cat. J Acoust Soc Am 48:950-965.

Winslow RL, Sachs MB (1987) Effect of electrical stimulation of the crossed olivocochlear bundle on auditory nerve response to tones in noise. J Neurophysiol 57:1002-1021.

Winslow RL, Sachs MB (1988) Single-tone intensity discrimination based on auditory-nerve rate responses in backgrounds of quiet, noise, and with stimulation of the crossed olivocochlear bundle. Hear Res 35:165-190.

Winter IM, Robertson D, Cole KS (1989) Descending projections from auditory brainstem nuclei to the cochlea and cochlear nucleus of the guinea pig. J Comp Neurol 280:143-157.

Womble MD, Moises HC (1992) Muscarinic inhibition of M-current and a potassium leak conductance in neurons of the rat basolateral amygdala. J Physiol (Lond) 457:93-114.

Wu SH, Oertel D (1984) Intracellular injection with horseradish peroxidase of physiologically characterized stellate and bushy cells in slices of mouse anteroventral cochlear nucleus. J Neurosci 4:1577-1588.
Wu SH, Oertel D (1987) Maturation of synapses and electrical properties of cells in the cochlear nuclei. Hear Res 30:99-110.

Yao W, Godfrey DA (1995) Immunohistochemistry of muscarinic acetylcholine receptors in rat cochlear nucleus. Hear Res 89:76-85.

Yao W, Godfrey DA (1996) Autoradiographic distribution of muscarinic acetylcholine receptor subtypes in rat cochlear nucleus. Aud Neurosci 2:241-255.

Yao W, Godfrey DA (1999) Immunolocalization of $\alpha 4$ and $\alpha 7$ subunits of nicotinic receptor in rat cochlear nucleus. Hear Res 128:97-102.

Yu CR, Role LW (1998) Functional contribution of the $\alpha 7$ subunit to multiple subtypes of nicotinic receptors in embryonic chick sympathetic neurons. J Physiol (Lond) 509:651-665.

Zhang S, Oertel D (1993) Cartwheel and superficial stellate cells of the dorsal cochlear nucleus of mice: intracellular recordings in slices. J Neurophysiol 69:1384-1397.

Zhang Z-W, Vijayaraghavan S, Berg DK (1994) Neuronal acetylcholine receptors that bind $\alpha$-bungarotoxin with high affinity function as ligand gated ion channels. Neuron 12:167-177.

Zhang Z-W, Coggan JS, Berg DK (1996) Synaptic currents generated by neuronal acetylcholine receptors sensitive to $\alpha$-bungarotoxin. Neuron 17:1231-1240. 